\title{
Zeolite minerals from the North Shore of the Minas Basin, Nova Scotia
}

\author{
Georgia Pe-Piper and Lisa Miller \\ Department of Geology, Saint Mary's University, Halifax, Nova Scotia, B3H 3C3, Canada \\ Date received:August 9, 2002 g Date accepted:December 2, 2002
}

\begin{abstract}
X-ray diffraction and electron microprobe analyses show the following assemblages to be present in basalt flows and overlying siliciclastic sedimentary rocks along the North Shore of the Minas Basin: Five Islands - chabazite and stilbite are dominant, also "heulandite" and barrerite; Two Islands - analcime is dominant, gmelinite, chabazite, stilbite, and natrolite; Wasson Bluff - chabazite, stilbite and "heulandite" are dominant, also herschelite, barrerite, stellerite, analcime, wairakite, natrolite, clinoptilolite, and thomsonite; Partridge Island - chabazite and stilbite are dominant, also analcime, epistilbite, natrolite, barrerite, and "heulandite"; Cape Sharp - chabazite, stilbite, barrerite, stellerite, and "heulandite"; Horseshoe Cove - "heulandite" and stilbite; Western Cape d'Or - analcime, stilbite, natrolite, and mesolite are dominant, also stellerite, ?epistilbite, barrerite, scolecite, chabazite, "heulandite", wairakite, tetranatrolite and laumontite. Comparison is made with assemblages at Arlington Quarry on North Mountain, where the dominant zeolite minerals are heulandite (sensu stricto) and stilbite. Elsewhere on North Mountain, mordenite, natrolite, and laumontite have been confirmed. Chemical composition of hydrothermal fluids was likely different between North Mountain and the North Shore, with fluids in the latter area less sodic. The temperature of zeolite crystallization appears to have been high at Arlington Quarry, where "heulandite" and stilbite crystallised with little Na in their crystal structure. With falling temperature the crystallizing solution became enriched in $\mathrm{Na}$, and sodic zeolite minerals, such as natrolite, began to crystallize. At lower temperatures on the North Shore, Na was accommodated in the structure of chabazite and other zeolites such as analcime, and final crystallisation was represented by only small amounts of Na-rich zeolites (natrolite group).

At Wasson Bluff, basalt flows of the North Mountain Basalt and overlying siliciclastic sediments of the McCoy Brook Formation are all dismembered by synchronous movement on the nearby left-lateral Portapique Fault. The dominant vesicle fillings in basalt are celadonite and silica minerals, with minor "heulandite", chabazite, and analcime. The oldest basaltic clasts in the McCoy Brook Formation contain a similar mineral assemblage (including sparse "heulandite" and chabazite) in amygdales, suggesting that the oldest zeolitization predated erosion of the clasts at fault scarps in the basalt. Zeolite minerals in the McCoy Brook Formation sedimentary rocks are restricted to a few discrete zones, including major faults. Massive veins within faults consist principally of chabazite. Rosettes of quartz and either "heulandite" or stellerite appear to have precipitated in situ in the muddy matrix of talus and debris-flow deposits within a few metres of these faults.
\end{abstract}

\section{RESUMÉ}

Les analyses par diffraction des rayons $\mathrm{X}$ et par microsonde électronique révèlent la présence des assemblages ci-après dans les coulées basaltiques et les roches sédimentaires silicoclastiques sus-jacentes le long du rivage nord du Minas Basin: Five Islands - prédominance de chabasite et de stilbite, ainsi qu' ' heulandite » et barrérite; Two Islands - analcime (prédominance), ainsi que gmélinite, chabasite, stilbite et natrolite; Wasson Bluff - prédominance de chabasite, de stilbite et « d'heulandite », ainsi qu'herschélite, barrérite, stellérite, analcime, wairakite, natrolite, clinoptilolite et thomsonite; Partridge Island - prédominance de chabasite et de stilbite, ainsi qu'analcime, épistilbite, natrolite, barrérite, et « heulandite »; Cape Sharp - chabasite, stilbite, barrérite, stellérite et " heulandite »; Horseshoe Cove - « heulandite » et stilbite; Cape d'Or Ouest - prédominance d'analcime, de stilbite, de natrolite et de mésolite, ainsi que stellérite, épistilbite, barrérite, scolécite, chabasite, « heulandite », wairakite, tétranatrolite et laumontite. Une comparaison a été effectuée avec des assemblages de la carrière Arlington au North Mountain, où les zéolites prédominantes sont l'heulandite (au sens strict) et la stilbite. Ailleurs au North Mountain, la présence de mordénite, de natrolite et de laumontite a été confirmée. La composition chimique des fluides hydrothermaux du North Mountain était vraisemblablement différente de celle des fluides de la côte nord, les fluides de cette dernière région étant moins sodiques. La température de cristallisation de la zéolite semble avoir été élevée dans la carrière Arlington, où l'« heulandite et la stilbite se sont cristallisées en intégrant peu de Na dans la structure de leurs cristaux. Avec la baisse de la température, la solution de cristallisation s'est enrichie en $\mathrm{Na}$, et les zéolites sodiques, comme la natrolite, ont commencé à se cristalliser. Aux températures inférieures de la côte nord, le Na a été incorporé dans la structure de la chabasite et des autres zéolites telles que l'analcime, et la cristallisation finale était représentée par des quantités réduites seulement de zéolites riches en $\mathrm{Na}$ (groupe de la natrolite).

À la Wasson Bluff, les coulées basaltiques du basalte du North Mountain et les sédiments silicoclastiques sus-jacents de la Formation de McCoy Brook sont tous démembrés par le mouvement synchrone exercé sur la faille latérale gauche voisine de Portapique. Les matières prédominantes remplissant les vacuoles dans le basalte sont la céladonite et la silice, en compagnie de petites quantités d' " heulandite », de chabasite et d'analcime. Les clastes basaltiques les plus âgés à l'intérieur de la Formation de McCoy Brook renferment un assemblage minéral analogue (notamment de l'« heulandite » et de la chabasite de faible densité) dans les géodes, ce qui laisse supposer que la zéolitisation la plus ancienne a précédé l'érosion des clastes aux escarpements des failles dans le basalte. Les zéolites dans les roches sédimentaires de la Formation de McCoy Brook se limitent à quelques zones distinctes, dont des failles importantes. Les filons massifs présents à l'intérieur des failles sont principalement constitués de chabasite. Des nodules de quartz et d'« heulandite » ou de stellérite semblent s'être précipités sur place dans la gangue boueuse du talus et les dépôts de coulées de débris à moins de quelques mètres de ces failles.

Atlantic Geology 38, 11-28 (2002)

$0843-5561|02| 01011-18 \$ 3.70 \mid 0$ 


\section{INTRODUCTION}

\section{Zeolites of the North Shore of the Minas Basin}

The earliest Jurassic (Hettangian) North Mountain Basalt of the Bay of Fundy has long been known for its rich assemblage of zeolite minerals in amygdales, vugs, and fractures (Aumento 1966). Some authors have compared the zeolite assemblages to those resulting from burial metamorphism in Iceland (Adams 1980), but more recent work on North Mountain shows them to result from hydrothermal circulation (De Wet and Hubert 1989; Pe-Piper 2000). The Minas Basin, at the eastern end of the Bay of Fundy, is a half-graben with the master fault on the north side showing strong left-lateral movement synchronous with basalt extrusion (Withjack et al. 1995). This area thus provides the opportunity to determine the relative timing of zeolite mineral formation, in relationship to synchronous faulting.

The North Shore of the Minas Basin is part of the CobequidChedabucto fault system that was active during the Triassic and Jurassic (Stevens 1987; Withjack et al. 1995). Basalt exposed on the North Shore shows the same stratigraphic succession as the main North Mountain outcrop on the south side of the Bay of Fundy, but tends to be more tectonized and altered (Greenough $e t$ al. 1989). The type section of the North Mountain basalt is overlain by the lacustrine Scots Bay Formation, whereas the basalt on the North Shore is overlain by siliciclastic rocks of the McCoy Brook Formation. The basalt of the North Shore hosts zeolites in pipes, joints, veins, fractures, cavities, and fault zones, and in the amygdales and groundmass of the basalt. The study areas of the North Shore include localities known as Five Islands, Two Islands, Wasson Bluff, Partridge Island, Cape Sharp, Horseshoe Cove, and western Cape d'Or (Fig. 1).

\section{Previous Work}

Previous work on the zeolites of the North Shore of the Minas Basin has been reported by Jackson and Alger (1828), Gesner (1836), How (1868), Gilpin (1881), Walker and Parsons (1922), Sabina (1965), Aumento (1966), Donohoe et al. (1992), and Booth (1994). Most of the studies of zeolite minerals on the North Shore were conducted before the development of analytical techniques such as X-ray diffraction and electron microprobe chemical analyses, and even the more recent studies have not included electron microprobe chemical analyses. Considerable discrepancy exists in the zeolite mineral assemblages in each area as reported by different authors.

\section{Purpose}

The purpose of this paper is: 1) to accurately identify zeolite minerals of the North Shore of the Minas Basin using up-to-date analytical techniques, thus establishing both their stratigraphic and regional distribution; 2) to determine the order of crystallization of zeolite minerals in each area and hence the events of zeolite formation; 3 ) to examine the chemical mineralogy of zeolite minerals of representative samples and in particular zeolite species from these areas with no published chemical analyses; 4) to establish the differences in chemistry of some identified zeolite species between the North Shore and the Arlington Quarry (a representative area of the type North Mountain basalt in Kings County) (Fig. 1). Both the field and analytical data in this study have been substantially updated since a preliminary report by Miller(1997).

\section{Methods}

Zeolite identification is based on hand-specimen identification, electron microprobe analysis, and X-ray diffraction (XRD) analysis. Two-hundred samples from the North Shore of the
FIG. 1 Map showing the North Mountain basalt (dark shading) in Nova Scotia and the sample localities along the North Shore of Minas Basin and Arlington Quarry.

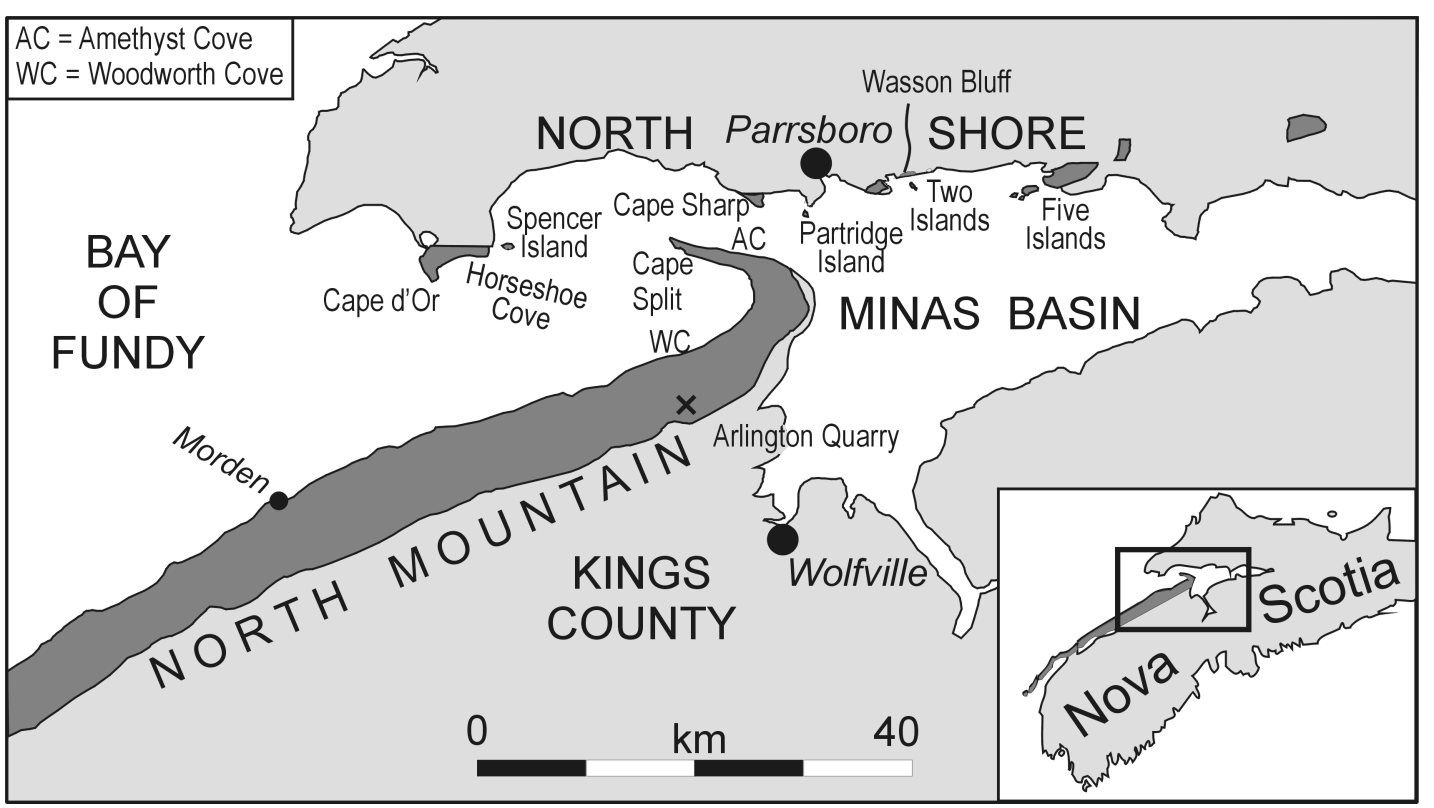


Minas Basin and seventy samples from Kings County have been studied.

Eighty-seven representative samples from the North Shore and eleven samples from Kings County were selected for X-ray diffraction. Potential zeolite minerals were extracted from each sample based on colour and crystal habit. Careful extraction of minerals helped increase the recovery of monomineralic samples and a microscope was employed to ensure purity of the mineral extracts. The extracts were then powdered using an agate mortar and pestle. A slurry of each of the powdered samples was created before mounting of the sample on a glass disk. Methanol was used in the slurry because it evaporates quickly and it does not react with zeolite minerals. The mixture of methanol and sample was then mounted on a glass slide using a micro-pipette and allowed to dry. The samples were then analysed using a Siemens Cristaloflex diffractometer, CoKo radiation, and a scan from $2^{\circ}$ to $42^{\circ} 2 \theta$ at a speed of $0.25^{\circ} 2 \theta / \mathrm{min}$. Peak positions were refined using the algorithm of Appleman and Evans (1973).

Thirty polished thin sections of representative specimens from the North Shore of the Minas Basin were prepared for detailed study by electron microprobe. These representative spots were analysed by a JEOL-733 with four wavelength spectrometers and a Tracor Northern 145-eV energy dispersive system detector at the Department of Earth Sciences, Dalhousie University. The beam operated with $15 \mathrm{kV}$ and $15 \mathrm{nA}$ and a beam diameter of $10 \mu \mathrm{m}$. An internal standard (scolecite) was used in addition to the standard regularly used. Because of the difficulty of discriminating accurately heulandite from clinoptilolite, we use the term "heulandite" to include both minerals.

Sequence of crystallisation of zeolites and other secondary minerals is based on two types of evidence. In individual veins, amygdales, and vugs, the sequence of minerals from rim to core is interpreted as a time sequence (Pe-Piper 2000). Where faulting and sedimentation was synchronous with zeolite formation, as at Wasson Bluff, geological field evidence can be used to determine the sequence of formation of secondary minerals.

\section{FIELD GEOLOGY OF STUDY AREAS}

\section{Introduction}

Study areas on the North Shore of the Minas Basin include Wasson Bluff, Cape Sharp, Five Islands, Partridge Island, Horseshoe Cove, Western Cape d'Or, and Two Islands (Fig. 1). Greenough et al. (1989) showed that basalt at Five Islands, Partridge Island, and Cape d'Or conformably overlying the Blomidon Formation is stratigraphically equivalent to the lower lava unit on North Mountain. They suggested that at McKay Head (not sampled in this study), a thick flow equivalent to the upper lava unit on North Mountain is overlain by several thinner flows and then by the McCoy Brook Formation. These thin flows are not recognised on North Mountain and appear to be correlative with the flows at Wasson Bluff.

\section{Wasson Bluff}

The Wasson Bluff section is the best area on the North Shore to study the geological events related to the formation of the zeolite-minerals (Figs. 2, 3). Most basalt in the area is massive, but considerable amounts are amygdaloidal. Zeolites at Wasson Bluff commonly occur in basalt, conglomerate with basalt clasts, and less commonly in sandstone, but on average make up no more than $3 \%$ of the overall rock. The zeolites are mainly found in veins, less commonly in cavities and the amygdales and groundmass of basalt, and only in a few fault zones. Sinistral strike-slip movement along the Portapique Fault, a few hundred metres north of the coastal outcrops, formed small transtensional grabens in which McCoy Brook Formation clastic sediments accumulated. The predominant lithology in the lower part of the McCoy Brook Formation is eolian dune sandstone, but lacustrine mudstone and talus slope debris-flow breccia of matrix-supported basalt clasts (Tanner and Hubert 1991) are also present. The upper part of the formation consists of red fluvial sandstone. Within the McCoy Brook Formation, slickensides in red sandstone and mudstone were interpreted by Schlische and Olsen (1989) as hydroplastic, having formed in incompletely lithified sediment.

The basalt has well developed columnar joints, some of which appear to have been rotated by local fault movement (Schlische and Olsen 1989). Neptunian dykes of fine red sandstone and mudstone occupy joints between cooling columns and sinuous fractures in the basalt (Figs. 2a, 2c, 2e; Fig. 3). They were interpreted by Schlische and Olsen (1989) to represent active tectonic extension of the North Mountain Basalt and filling of fractures by sediment from above. The widest neptunian dykes are orthogonal to the regional extension direction. Schlische and Olsen (1989) also described extensive outcrops of "rubblized" basalt (Fig. 3), which is cataclastic basalt brecciated along strike-slip fault zones. They also described irregularities in the top of one basalt flow developed before the subsequent flow was deposited that they ascribed to faulting during extrusion of the basalt succession.

Others have made passing observations on the distribution of zeolites in the Wasson Bluff section. Tanner and Hubert (1991) noted that the talus slope breccia included zeolite-filled fractures cutting both clasts and matrix. Schlische and Olsen (1989) noted that narrow neptunian dykes are commonly silicified, and that cataclastic basalt contains chabazite, but some faults that they interpreted as almost syn-depositional lack zeolite mineralisation.

New field observations clarify the occurrence of zeolites in the Wasson Bluff section (Fig. 3). Amygdaloidal basalt flows have amygdale fillings principally of celadonite and silica minerals, with minor amounts of zeolite. Clasts in the talus-slope and debris-flow deposits (Fig. 2b) are similar, principally with celadonite and silica minerals in amygdales. Slickensides in the basalt cataclasite are developed in quartz and celadonite.

Where columnar joints in basalt have been progressively widened, they commonly filled with neptunian dykes of red sandstone and mudstone (Fig. 2a). In the basalt, zeolites are common in some thinner joints with neptunian dykes (Fig. 2e). Zeolites fill vugs in the basalt. A few zeolite veins cross-cut both 

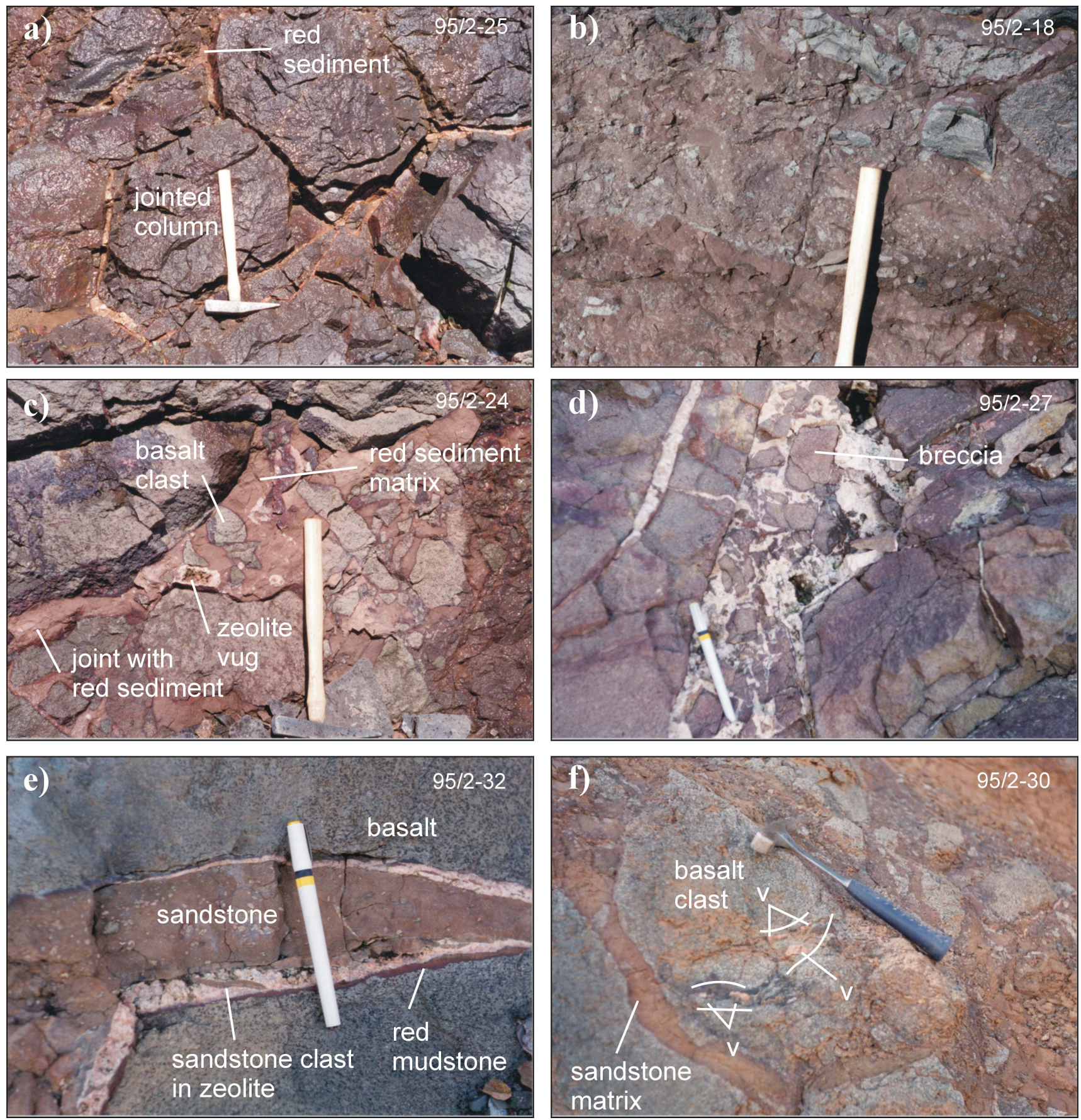

FIG. 2 Field photographs of representative outcrops at Wasson Bluff. a) Basalt with columnar jointing and brownish mudstone filling the joints. Zeolites (chabazite, stilbite, "heulandite") and quartz fill the joints and the amygdales of the basalt. b) Talus breccia of basalt clasts overlying in-situ basalt.c) Talus breccia of basalt clasts in a matrix of red sandstone. Note the vug in the red sandstone matrix that is filled with zeolites (chabazite) and rimmed by a fine grained mixture of quartz and "heulandite." d) Fault breccia of basalt clasts cemented by zeolites (chabazite, "heulandite," stilbite) and quartz in a fault or joint in the basalt.e) Complex fill of a joint in basalt with the following order of formation: phase 1, red mudstone deposition; phase 2, zeolite precipitation; phase 3, sandstone deposition (see clast); phase 4, zeolite precipitation; phase 5, deposition of central sandstone. f) Talus breccia of basalt clasts in a red sandstone matrix. Note chabazite veins $(v)$ in large basalt clast. g) Talus breccia of basalt clasts with veins of zeolite (mainly chabazite) and of quartz. h) Polymictic basalt conglomerate 

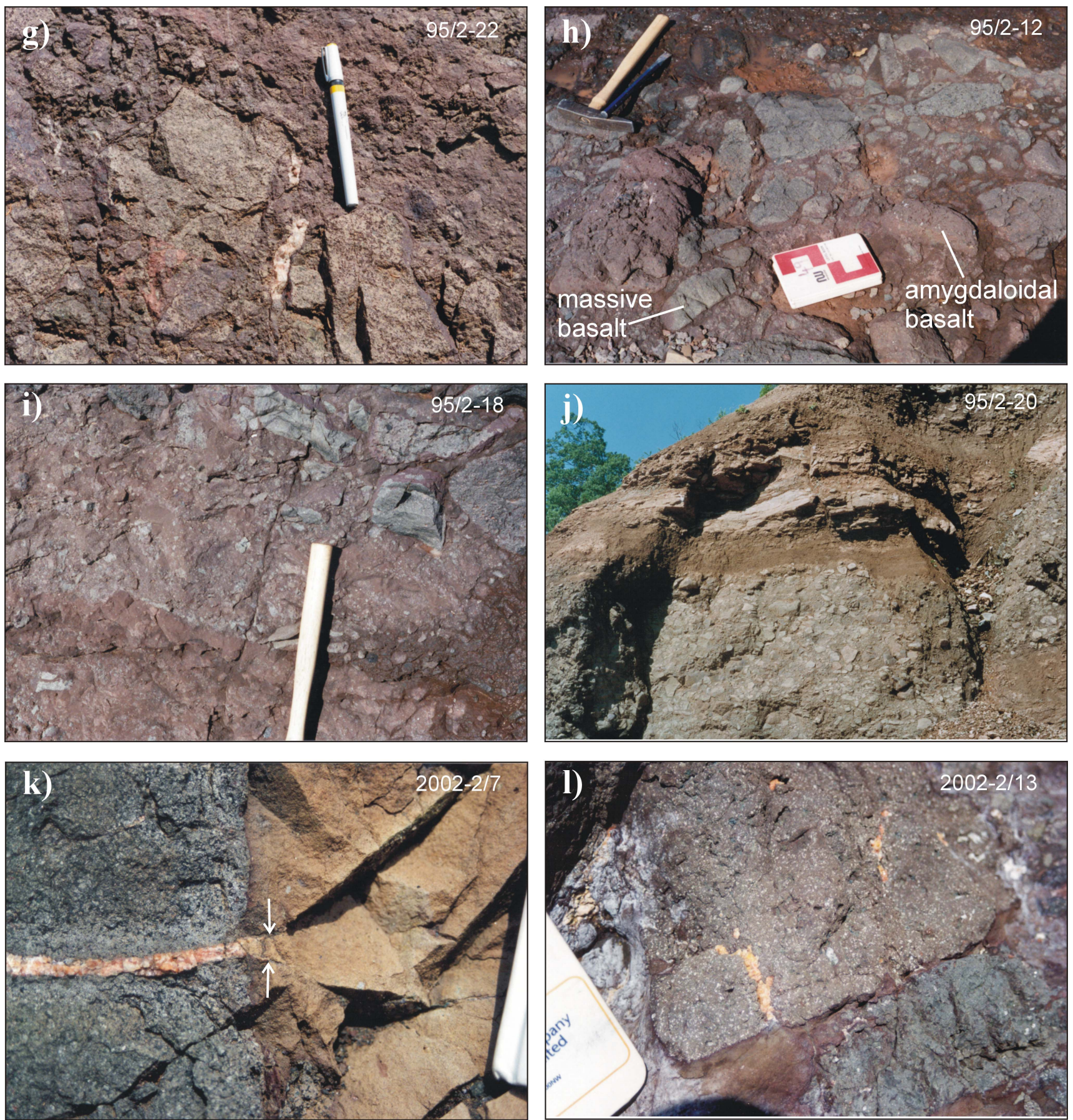

with red sandy matrix. Basalt clasts are either massive or amygdaloidal with amygdales filled with zeolite (analcime). i) Polymictic conglomerate with rounded clasts of a range of basalt types cut by joint. Cavities in the red sandstone matrix filled with chabazite and quartz and amygdales in the amygdaloidal basalt clasts are filled with chabazite, laumontite, and quartz.j) Polymictic conglomerate with rounded clasts of a range of basalt types that overlies red mudstone and is interbedded with sandstone. Fault with $60 \mathrm{~cm}$ throw visible where it offsets sandstone and does not contain zeolite. Rare zeolite occurs in the matrix of the conglomerate. $k$ ) Basalt and joint filled with brown siltstone. Chabazite vein cuts basalt and bifurcates into two $1 \mathrm{~mm}$ wide veins in the siltstone. l) Talus breccia with chabazite vein in basalt block that appears to predate breccia deposition. 
columnar jointed basalt flow
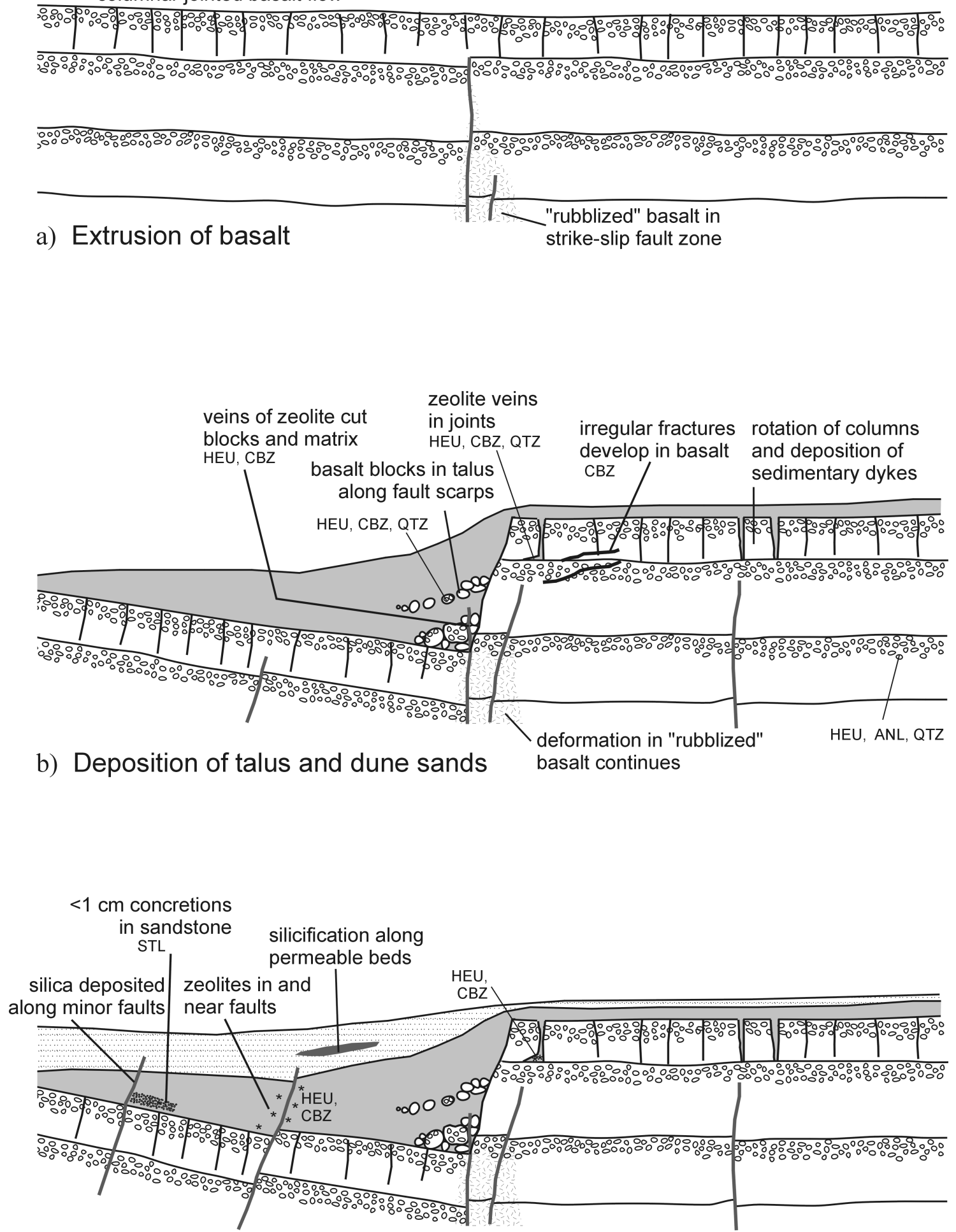

c) Deposition of fluvial sands

FIG. 3 Schematic cross-sections (not to scale) showing relationship of zeolites in the North Mountain basalt and McCoy Brook Formation to syn-depositional faulting at Wasson Bluff. 
the basalt and neptunian dykes, but are much thinner in the dyke sediments (Fig. $2 \mathrm{k}$ ), presumably reflecting the greater brittleness of the basalt. Some of the thinner neptunian dykes appear to be silicified (Schlische and Olsen 1989). Zeolites also cement zones where basalt has been brecciated (Fig. 2d). Veins of zeolite cutting basalt are also recognised in basalt clasts in the talus-slope deposits (Fig. 2l).

Zeolites occur only locally in the McCoy Brook Formation. Zeolite veins cut the talus-slope deposits and zeolites also fill vugs in the matrix. Zeolites are also present as irregular veins in the pug of a few major faults. Zeolite rosettes $5-20 \mathrm{~mm}$ in diameter appear to have precipitated in situ in the muddy matrix of the debris-flow deposits within a few metres of these faults. Some eolian sandstone has abundant patches of concretions 5-10 mm in diameter that consist of sandstone cemented by stellerite. In the easternmost McCoy Brook Formation basin, an irregular silicified body (5 $\mathrm{m}$ in length, $1 \mathrm{~m}$ thick) appears to have replaced permeable polymictic coarse litharenite. (The outcrops are inaccessible in the cliff, but have been sampled from modern talus).

The fault zone cutting sandstone of the McCoy Brook Formation that shows hydroplastic slickensides described by Schlische and Olsen (1989) also has sub-parallel zeolite veins and veins of silicified sediment. Thin silica veins have been found in other faults cutting sandstone of the McCoy Brook Formation.

In summary, the work of Schlische and Olsen (1989) showed that extrusion of North Mountain Basalt and deposition of the immediately overlying sediments of the McCoy Brook Formation took place during active strike-slip faulting and the formation of a small transtensional graben (Fig. 3). The oldest basaltic clasts in the McCoy Brook Formation contain sparse zeolite in amygdales even where matrix zeolite is absent, suggesting that the oldest zeolitization predated erosion of the clasts at fault scarps in the basalt. However, the predominant zeolitization appears to affect the McCoy Brook Formation and the North Mountain Basalt equally. In the North Mountain Basalt, the most prominent zeolitization is in the columnar-jointed basalt and irregular veins and vugs, which is a response to the progressive deformation of the basalt in a strike-slip, pull-apart setting. Within the McCoy Brook Formation, zeolitization is generally restricted to a few discrete zones, including major faults and near the contact of talus-slope deposits with basalt (again, presumably related to active faulting). Nevertheless, significant silicic alteration affects the upper part of the McCoy Brook Formation containing polymictic pebbly litharenite. Rocks younger than the McCoy Brook Formation are not present in the region, so that the age of the youngest zeolitization cannot be determined.

\section{Other North Shore localities}

Other North Shore localities are described from east to west. At Five Islands, the North Mountain Basalt is highly faulted (Greenough et al. 1989; Stevens 1987; Olsen 1989). Basaltic cataclasite contains only rare zeolites, as at Wasson Bluff. Basaltic breccia with a red mudstone matrix, probably a faulted equivalent of the talus slope breccia seen at Wasson Bluff, contains zeolites, principally in veins, although some occur in vugs in the matrix and in amygdales in the basalt clasts.

At Two Islands, the larger island is entirely basalt and has common gmelinite and analcime. Massive basalt at Partridge Island, corresponding to the lower lava unit of North Mountain, conformably overlies the Blomidon Formation. Zeolites in the basalt are mostly in veins and less commonly in cavities.

The vesicular and jointed basalt at Cape Sharp also overlies red sandstone of the Blomidon Formation. Zeolite samples were collected on the east side of the headland and are common in joints, veins, and vugs.

Zeolites from basalt at Cape d'Or were collected from both Horseshoe Cove in the east and the western part of Cape d'Or near the lighthouse. The host rock is mostly locally vesicular basalt (some joints filled with red sandstone) overlain by massive basalt. Zeolites are common in veins and at western Cape d'Or, also in joints.

\section{SUMMARY OF DIAGNOSTIC FIELD APPEARANCE OF THE VARIOUS ZEOLITE MINERALS}

Sixteen zeolite minerals have been identified along the North Shore of the Minas Basin. They are "heulandite" (heulandite sensu stricto and clinoptilolite), chabazite, analcime, stilbite, barrerite, epistilbite, gmelinite, laumontite, natrolite, mesolite, scolecite, stellerite, tetranatrolite, thomsonite, and wairakite. The first four minerals are the most common. Identifying zeolites in the field was difficult because commonly more than one zeolite mineral was present in any one hand specimen. The following physical properties were found to be most useful for zeolite mineral identification in the field. Field identification was confirmed by X-ray diffraction and electron microprobe chemical analyses.

Analcime is generally vitreous and granular (Fig. 4b), either pink or colourless. Most crystals are well formed and easily identified, but the massive form resembles massive heulandite, making positive identification by eye difficult. Analcime from Wasson Bluff is commonly present as well formed trapezohedra growing on other crystals such as twinned heulandite.

Barrerite is generally vitreous, massive, and colourless to pink (Fig. 4c).

Chabazite is usually vitreous and salmon pink, yellow, or colourless. It commonly occurs in cubic rhombohedra and is rarely massive.

Epistilbite is generally vitreous and colourless to pink.

Gmelinite is generally pink and vitreous with well formed colourless hexagonal dipyramid, prism and pinacoid crystals (Fig. 4e).

"Heulandite" is generally vitreous and colourless to pink to reddish orange (Fig. 4b). Well crystallized "heulandite" can easily be identified by its coffin-shaped crystal habit. Massive light-pink "heulandite" identified by XRD resembled chabazite in hand specimen.

Laumontite is milky white and subvitreous to vitreous. The star-like crystal habit is distinctive. 

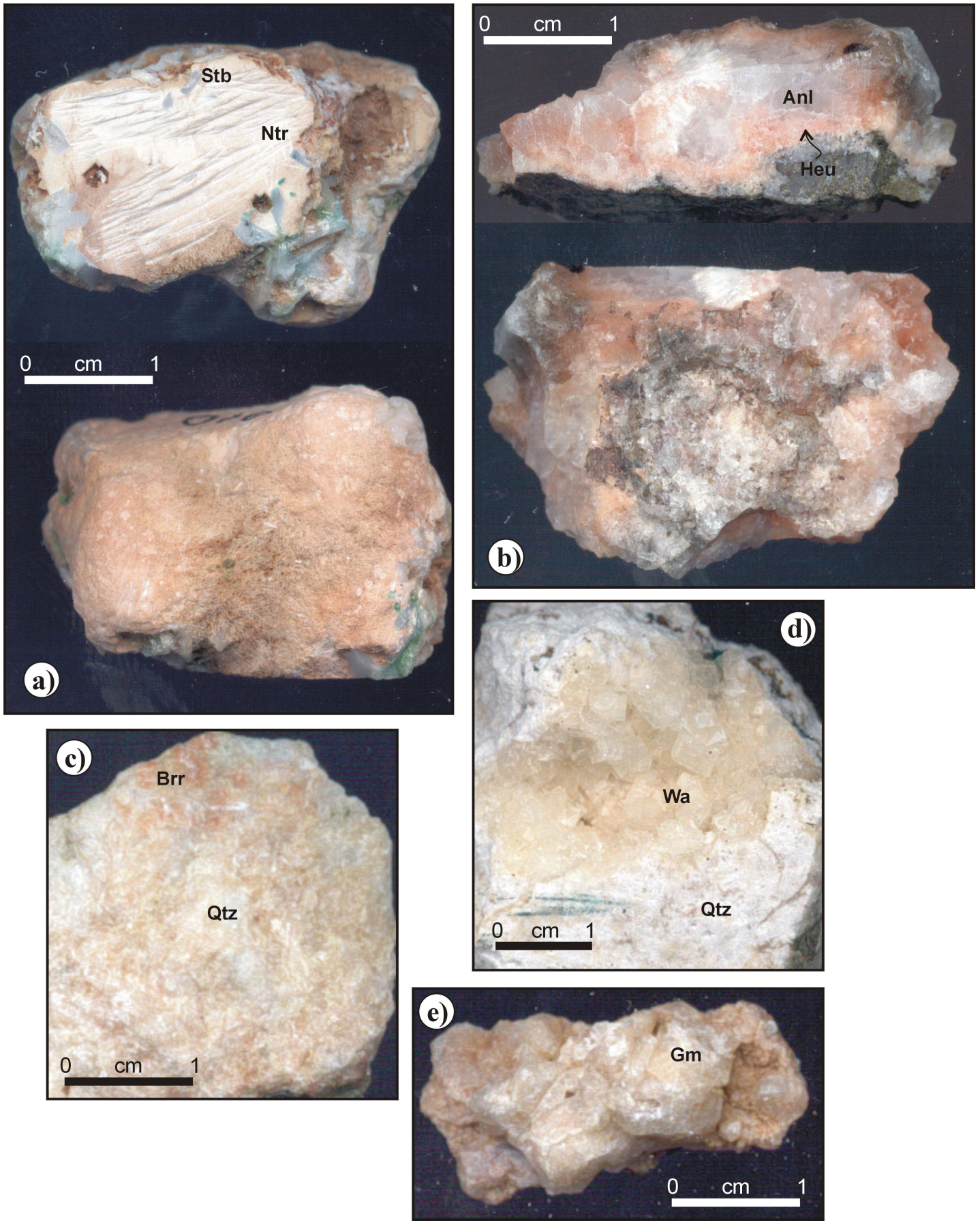

FIG. 4 Photographs of representative hand specimens. a) Very fine grained, massive pinkish natrolite (Ntr) with stilbite (Stb) blades rimming and embedded in the natrolite; sample Z310 from Cape d'Or. b) Clear crystals of analcime (Anl) in the middle rimmed by pinkish "heulandite" (Heu) crystals; sample Z51 from Wasson Bluff.c) Fibres and grains of pinkish barrerite (Brr) intermixed with quartz (Qtz); sample W168 from Partridge Island. d) Transparent colourless monoclinic crystals of wairakite (Wa) on massive fine-grained quartz (Qtz); sample Z675 from Cape d'Or. e) Transparent crystals of gmelinite (Gm); sample W198 from Two Islands. 
Mesolite is generally milky white and fibrous with fibres larger than those of natrolite. It can also be massive, white, and dull.

Natrolite is generally beige to white, massive or as radiating fibres, dull, and brittle (Fig. 4a).

Scolecite was not identified in the field and detected only by $\mathrm{XRD}$.

Stellerite was identified only by XRD and chemical analysis, but in hand specimen resembles stilbite.

Stilbite commonly occurs as vitreous sheaves or plates (Fig. 4a), ranging from colourless to green to white.

Tetranatrolite resembles natrolite and was identified only by chemical analysis.

Thomsonite is generally massive or fibrous, beige to off-white.

Wairakite is generally vitreous with well formed pseudo-octahedral to pseudo-icositetrahedral colourless crystals that can be confused with analcime (Fig. 4d).

\section{GEOGRAPHIC VARIATION IN ZEOLITE MINERALOGY}

\section{Introduction}

The zeolite mineral assemblages vary in each study locality on the North Shore of the Minas Basin. Wasson Bluff and Cape d'Or display the largest variety of zeolite minerals, whereas the other localities have only two to five zeolite minerals. Minerals associated with the zeolite minerals include quartz and other forms of silica (e.g., chalcedony, amethyst, agate, jaspar, opal), malachite, mica, barite, and calcite.

\section{Wasson Bluff}

The zeolites we identified at this locality are the same as those reported by Booth (1994) and Donohoe et al. (1992), except that we did not identify scolecite and epistilbite. Chabazite is the dominant zeolite, occurring most commonly in veins. The term "acadialite" has been applied by previous workers to the pink variety of chabazite. Stilbite, "heulandite", and analcime are common, natrolite and thomsonite are rare. The associated minerals include quartz, calcite, and barite.

Based on textural relationships between minerals in individual hand specimens, the following sequences of crystallization are recognised, from early to late:

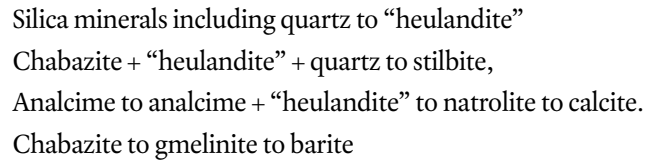

On geological criteria, the relative timing of crystallisation is much less clear. Celadonite, silica minerals, "heulandite," analcime, and chabazite predominate in amygdales in the basalt flows and in basalt clasts in the McCoy Brook Formation, suggesting that these minerals were "early" (Fig. 3). The McCoy Brook Formation sedimentary rocks are host to, or cut by veins of, "heu- landite", chabazite, stellerite, and silica minerals. Late fractures in the basalt flows predominantly contain chabazite.

\section{Five Islands}

The zeolites identified in the Five Island area are chabazite, "heulandite", barrerite, and stilbite. Walker and Parsons (1922) reported analcime, natrolite, thomsonite, and gmelinite, but we have not identified those minerals in our samples. Calcite, silica minerals, and barite, the last of which occurs alone or with quartz, are commonly associated with the zeolite minerals.

\section{Two Islands}

The most abundant zeolite on the larger island is analcime, whereas gmelinite and chabazite are common and stilbite and natrolite are rare (I. Booth, personal communication, 1999). We have analysed gmelinite and analcime, with gmelinite having been the first to crystallize.

\section{Partridge Island}

Chabazite and stilbite are abundant among our studied samples; "heulandite", barrerite, epistilbite, and natrolite are rare. We have not identified thomsonite, reported by Booth (1994). Associated minerals are quartz, chert, other forms of silica, mica, chlorite, magnetite, and galena. The overall order of crystallization from earliest to latest is: chabazite to quartz + stilbite to calcite.

\section{Cape Sharp}

Stilbite is abundant and chabazite is common in the area, with minor "heulandite" and barrerite. Gesner (1836) reported that a mass of stilbite of over $200 \mathrm{lbs}$ fell from a cliff in 1834. Gmelinite was reported by Gilpin (1881) and natrolite by Walker and Parsons (1922), but we did not identify those zeolite minerals. The overall order of crystallization from earliest to latest is: mica to quartz + amethyst + other forms of silica to chabazite to stilbite to calcite.

\section{Horseshoe Cove}

Although "heulandite" occurrences were not suggested in earlier studies, this zeolite is abundant in the samples examined. Stilbite is common and associated minerals are quartz and calcite. The overall order of crystallization is: quartz to stilbite + quartz to stilbite to "heulandite" to calcite. The precipitation of "heulandite", a high-temperature zeolite, after stilbite, a lower temperature zeolite, is noteworthy.

\section{Cape d'Or}

Analcime and natrolite are abundant, mesolite and stilbite are common, and thomsonite, chabazite, laumontite, and "heulandite" are rare. The "heulandite" is present in the form of rosettes. Tetranatrolite, stellerite, barrerite, scolecite, and wairakite have 
Table 1. Electron microprobe analyses of representative zeolite minerals.

\begin{tabular}{|c|c|c|c|c|c|c|c|c|c|c|c|c|c|c|}
\hline \multirow{4}{*}{$\begin{array}{l}\text { Mineral } \\
\text { Sample } \\
\text { Analysis No. } \\
\text { Locality }\end{array}$} & \multicolumn{3}{|c|}{ Mesolite } & \multirow{2}{*}{\multicolumn{3}{|c|}{$\begin{array}{c}\text { Thomsonite } \\
\text { Z51 }\end{array}$}} & \multicolumn{6}{|c|}{ Analcime } & \multirow{2}{*}{\multicolumn{2}{|c|}{$\begin{array}{c}\text { Wairakite } \\
\text { Z51 }\end{array}$}} \\
\hline & \multirow{2}{*}{$\frac{\mathrm{Z} 270}{141}$} & \multicolumn{2}{|c|}{ Z401 } & & & & \multicolumn{2}{|c|}{ W102 } & \multicolumn{2}{|c|}{ Z51 } & \multicolumn{2}{|c|}{$\mathrm{Z} 270$} & & \\
\hline & & 131 & 132 & 91 & 92 & 93 & 46 & 47 & 90 & 94 & 142 & 146 & 97 & 98 \\
\hline & \multicolumn{3}{|c|}{ Cape d'Or } & \multicolumn{3}{|c|}{ Wasson Bluff } & \multicolumn{4}{|c|}{ Wasson Bluff } & \multicolumn{2}{|c|}{ Cape d'Or } & \multicolumn{2}{|c|}{ Wasson Bluff } \\
\hline \multicolumn{15}{|c|}{ Major elements (wt \%) } \\
\hline $\mathrm{SiO}_{2}$ & 48.05 & 47.14 & 47.63 & 42.31 & 42.04 & 42.02 & 58.38 & 57.75 & 57.94 & 58.02 & 59.24 & 59.01 & 55.14 & 57.42 \\
\hline $\mathrm{Al}_{2} \mathrm{O}_{3}$ & 25.46 & 25.15 & 25.22 & 28.40 & 28.78 & 28.34 & 21.09 & 21.47 & 21.93 & 22.05 & 22.27 & 21.95 & 17.65 & 18.34 \\
\hline $\mathrm{CaO}$ & 8.78 & 9.45 & 9.66 & 11.00 & 11.20 & 11.32 & b.d. & b.d. & b.d. & b.d. & b.d. & b.d. & 8.70 & 7.66 \\
\hline $\mathrm{Na}_{2} \mathrm{O}$ & 6.00 & 4.97 & 5.11 & 5.45 & 5.18 & 5.45 & 12.06 & 13.02 & 13.27 & 13.61 & 13.41 & 13.42 & 4.59 & 3.53 \\
\hline $\mathrm{K}_{2} \mathrm{O}$ & b.d. & b.d. & b.d. & b.d. & b.d. & b.d. & b.d. & b.d. & b.d. & b.d. & b.d. & b.d. & 1.03 & 0.86 \\
\hline Total & 88.29 & 86.71 & 87.62 & 87.16 & 87.20 & 87.13 & 91.53 & 92.24 & 93.14 & 93.68 & 94.92 & 94.38 & 87.11 & 87.81 \\
\hline \multicolumn{15}{|c|}{ Molecular formula } \\
\hline Oxygen No. & 80 & 80 & 80 & 80 & 80 & 80 & 96 & 96 & 96 & 96 & 96 & 96 & 96 & 96 \\
\hline $\mathrm{Si}$ & 24.59 & 24.54 & 24.56 & 22.28 & 22.13 & 22.18 & 33.70 & 33.38 & 32.20 & 33.11 & 33.28 & 33.35 & 33.95 & 34.57 \\
\hline $\mathrm{Al}$ & 15.36 & 15.43 & 15.33 & 17.63 & 17.86 & 17.64 & 14.36 & 14.63 & 14.82 & 14.83 & 14.75 & 14.63 & 12.81 & 13.02 \\
\hline $\mathrm{Ca}$ & 4.81 & 5.27 & 5.34 & 6.21 & 6.32 & 6.40 & b.d. & b.d. & b.d. & b.d. & b.d. & b.d. & 5.74 & 4.94 \\
\hline $\mathrm{Na}$ & 5.95 & 5.02 & 5.11 & 5.57 & 5.29 & 5.58 & 14.12 & 14.59 & 14.75 & 15.06 & 14.61 & 14.71 & 5.48 & 4.12 \\
\hline K & b.d. & b.d. & b.d. & b.d. & b.d. & b.d. & b.d. & b.d. & b.d. & b.d. & b.d. & b.d. & 0.81 & 0.66 \\
\hline $\mathrm{Si} / \mathrm{Al}$ & 1.60 & 1.59 & 1.60 & 1.26 & 1.24 & 1.26 & 2.35 & 2.28 & 2.17 & 2.23 & 2.26 & 2.28 & 2.65 & 2.66 \\
\hline $\mathrm{E} \%$ & -1.4 & -0.8 & -2.9 & -1.9 & -0.3 & -4.1 & 1.7 & 0.3 & 0.5 & -1.5 & 1.0 & -0.6 & -27.9 & -11.2 \\
\hline Mineral & \multicolumn{4}{|c|}{ Wairakite } & \multicolumn{4}{|c|}{ Chabazite } & \multicolumn{6}{|c|}{ Stilbite } \\
\hline Sample & \multicolumn{2}{|c|}{ Z675 } & \multicolumn{2}{|c|}{ Z675 } & $\mathrm{Z6}$ & & W1 & & $\mathrm{Z3}$ & & & $\mathrm{Z4}$ & & \\
\hline Analysis No. & 161 & 162 & 163 & 164 & 8 & 9 & 52 & 53 & 20 & 21 & 125 & 126 & 128 & 130 \\
\hline Locality & & Cape & 'Or & & Wasso & Bluff & Partri & ge Is. & & & Cape & 'Or & & \\
\hline Major eleme & (0) & & & & & & & & & & & & & \\
\hline $\mathrm{SiO}_{2}$ & 59.69 & 57.08 & 57.76 & 58.01 & 53.85 & 54.39 & 51.72 & 52.41 & 55.29 & 56.65 & 57.23 & 57.87 & 58.30 & 57.83 \\
\hline $\mathrm{Al}_{2} \mathrm{O}_{3}$ & 19.49 & 19.18 & 19.12 & 18.84 & 17.31 & 17.55 & 16.67 & 16.05 & 16.72 & 16.20 & 16.40 & 15.90 & 16.82 & 16.84 \\
\hline $\mathrm{CaO}$ & 8.58 & 8.58 & 8.07 & 8.80 & 8.02 & 7.19 & 0.77 & 0.62 & 7.93 & 8.11 & 6.29 & 6.55 & 7.42 & 6.38 \\
\hline $\mathrm{Na}_{2} \mathrm{O}$ & 2.58 & 3.32 & 3.81 & 2.79 & 3.85 & 4.63 & 9.02 & 8.44 & 1.06 & 0.59 & 1.55 & 2.01 & 0.83 & 0.93 \\
\hline $\mathrm{K}_{2} \mathrm{O}$ & 0.68 & 0.85 & 0.70 & 0.67 & 0.82 & 0.95 & 4.75 & 4.73 & b.d. & b.d. & 0.68 & 0.62 & 0.42 & 0.75 \\
\hline Total & 991.02 & 89.01 & 89.46 & 89.11 & 83.85 & $\overline{84.71}$ & 82.93 & 82.25 & $\overline{81.00}$ & 81.55 & 82.15 & 82.95 & 83.79 & 82.73 \\
\hline Mole & & & & & & & & & & & & & & \\
\hline Oxygen No. & 96 & 96 & 96 & 96 & 24 & 24 & 24 & 24 & 72 & 72 & 72 & 72 & 72 & 72 \\
\hline $\mathrm{Si}$ & 34.53 & 34.03 & 34.20 & 34.40 & 8.55 & 8.55 & 8.53 & 8.67 & 26.60 & 26.98 & 27.08 & 27.19 & 27.02 & 27.10 \\
\hline $\mathrm{Al}$ & 13.29 & 13.48 & 13.35 & 13.17 & 3.24 & 3.25 & 3.24 & 3.13 & 9.48 & 9.09 & 9.15 & 8.81 & 9.19 & 9.30 \\
\hline $\mathrm{Ca}$ & 5.32 & 5.48 & & 5.59 & 1.37 & 1.21 & 0.14 & 0.11 & 4.09 & 4.14 & 3.19 & 3.30 & 3.68 & 3.20 \\
\hline $\mathrm{Na}$ & 2.89 & 3.84 & 4.38 & 3.21 & 1.19 & 1.41 & 2.89 & 2.71 & 0.99 & 0.55 & 1.42 & 1.83 & 0.75 & 0.85 \\
\hline K & 0.50 & 0.65 & 0.53 & 0.51 & 0.17 & 0.19 & 1.00 & 1.00 & b.d. & b.d. & 0.41 & 0.37 & 0.25 & 0.45 \\
\hline $\mathrm{Si} / \mathrm{Al}$ & 2.60 & 2.52 & 2.56 & 2.61 & 2.64 & 2.63 & 2.63 & 2.77 & 2.81 & 2.97 & 2.96 & 3.09 & 2.94 & 2.91 \\
\hline $\mathrm{E} \%$ & -5.3 & -12.7 & -1.0 & -11.6 & -20.6 & -19.2 & -22.0 & -20.3 & 3.5 & 3.1 & 11.4 & 0.1 & 9.9 & 20.8 \\
\hline
\end{tabular}

b.d. $=$ below detection limit; $\mathrm{E}=$ chemical balance error, $\left[\left(\mathrm{Al}+\mathrm{Fe}^{3+}\right)-\mathrm{Al}_{\text {theor }}\right] \times 100 / \mathrm{Al}_{\text {theor }}(\operatorname{after}$ Passaglia 1975) 
Table 1. (contd.)

\begin{tabular}{|c|c|c|c|c|c|c|c|c|c|c|c|c|c|c|}
\hline \multirow{4}{*}{$\begin{array}{l}\text { Mineral } \\
\text { Sample } \\
\text { Analysis No. } \\
\text { Locality }\end{array}$} & \multirow{2}{*}{\multicolumn{3}{|c|}{$\begin{array}{c}\text { Gmelinite } \\
\text { W193 }\end{array}$}} & \multicolumn{11}{|c|}{ "Heulandite" } \\
\hline & & & & \multirow{2}{*}{$\frac{\text { W108 }}{40}$} & \multicolumn{2}{|c|}{ W102 } & \multirow{2}{*}{$\begin{array}{l}\text { W88 } \\
176\end{array}$} & \multirow{2}{*}{$\frac{\mathrm{W} 120}{180}$} & \multicolumn{2}{|c|}{ W94 } & \multicolumn{4}{|c|}{ W153 } \\
\hline & 108 & 109 & 111 & & 48 & 49 & & & 190 & 191 & 99 & 101 & 102 & 105 \\
\hline & \multicolumn{3}{|c|}{ Two Islands } & \multicolumn{7}{|c|}{ Wasson Bluff } & \multicolumn{4}{|c|}{ Cape Sharp } \\
\hline \multicolumn{15}{|c|}{ Major elements (wt \%) } \\
\hline $\mathrm{SiO}_{2}$ & 52.55 & 53.22 & 51.39 & 66.27 & 57.61 & 58.88 & 57.19 & 58.05 & 55.44 & 55.17 & 57.68 & 59.75 & 59.12 & 58.55 \\
\hline $\mathrm{Al}_{2} \mathrm{O}_{3}$ & 19.42 & 19.62 & 19.03 & 12.38 & 16.81 & 16.54 & 16.88 & 15.67 & 17.99 & 17.83 & 16.33 & 16.30 & 16.43 & 16.16 \\
\hline $\mathrm{CaO}$ & 4.20 & 5.28 & 4.60 & 5.84 & 5.05 & 5.24 & 4.71 & 5.97 & 8.11 & 7.98 & 7.79 & 8.46 & 8.28 & 7.83 \\
\hline $\mathrm{Na}_{2} \mathrm{O}$ & 10.26 & 8.49 & 13.16 & 0.57 & 1.11 & 0.40 & 0.70 & 0.73 & 0.49 & 0.59 & 0.71 & 0.74 & 0.74 & 0.59 \\
\hline $\mathrm{K}_{2} \mathrm{O}$ & 0.28 & 0.32 & 0.16 & 0.46 & 1.31 & 1.09 & 2.40 & 0.74 & 2.60 & 2.56 & b.d. & b.d. & b.d. & b.d. \\
\hline $\mathrm{BaO}$ & b.d. & b.d. & b.d. & b.d. & b.d. & 0.62 & b.d. & b.d. & 1.56 & 1.80 & b.d. & b.d. & b.d. & b.d. \\
\hline $\mathrm{SrO}$ & b.d. & b.d. & b.d. & b.d. & 0.69 & 0.54 & 4.18 & 1.91 & b.d. & b.d. & b.d. & b.d. & b.d. & b.d. \\
\hline Total & 86.71 & 86.93 & 88.34 & 85.97 & 82.58 & 83.01 & 86.06 & 83.07 & 86.19 & 85.93 & 82.51 & 85.25 & 84.57 & 83.13 \\
\hline \multicolumn{15}{|c|}{ Molecular formula } \\
\hline Oxygen No. & 48 & 48 & 48 & 72 & 72 & 72 & 72 & 72 & 72 & 72 & 72 & 72 & 72 & 72 \\
\hline $\mathrm{Si}$ & 16.37 & 16.46 & 16.00 & 29.39 & 27.24 & 27.55 & 27.18 & 27.61 & 26.00 & 26.03 & 27.10 & 27.21 & 27.13 & 27.26 \\
\hline $\mathrm{Al}$ & 7.13 & 7.15 & 6.98 & 6.71 & 9.37 & 9.17 & 9.46 & 8.79 & 9.95 & 9.92 & 9.04 & 8.75 & 8.89 & 8.87 \\
\hline $\mathrm{Ca}$ & 1.40 & 1.75 & 1.53 & 2.78 & 2.56 & 2.64 & 2.40 & 3.04 & 4.08 & 4.03 & 3.92 & 4.13 & 4.07 & 3.91 \\
\hline $\mathrm{Na}$ & 6.20 & 5.09 & 7.94 & 0.49 & 1.02 & 0.37 & 0.65 & 0.67 & 0.45 & 0.54 & 0.65 & 0.65 & 0.66 & 0.53 \\
\hline K & 0.11 & 0.13 & 0.06 & 0.26 & 0.79 & 0.66 & 1.46 & 0.45 & 1.56 & 1.54 & b.d. & b.d. & b.d. & b.d. \\
\hline $\mathrm{Si} / \mathrm{Al}$ & 2.30 & 2.30 & 2.29 & 4.38 & 2.91 & 3.00 & 2.87 & 3.14 & 2.61 & 2.62 & 3.00 & 3.11 & 3.05 & 3.07 \\
\hline $\mathrm{E} \%$ & -21.7 & -17.9 & -36.9 & 6.5 & 35.3 & 45.4 & 37.1 & 21.9 & -2.0 & -2.3 & 6.5 & -1.8 & 1.0 & 6.3 \\
\hline \multirow{4}{*}{$\begin{array}{l}\text { Mineral } \\
\text { Sample } \\
\text { Analysis No. } \\
\text { Locality }\end{array}$} & \multicolumn{2}{|c|}{ Epistilbite } & \multicolumn{2}{|c|}{ Barrerite } & \multicolumn{8}{|c|}{ Natrolite } & \multicolumn{2}{|c|}{ Tetranatrolite } \\
\hline & W166 & W176 & \multicolumn{2}{|c|}{ W168 } & \multicolumn{3}{|c|}{ Z303 } & & $\mathrm{Z} 270$ & & $\mathrm{Z3}$ & & $\mathrm{Z2}$ & 0 \\
\hline & 50 & 65 & 57 & 58 & 114 & 116 & 119 & 149 & 151 & 152 & 22 & 24 & 138 & 139 \\
\hline & Partri & ge Is. & Part & ge Is. & & & & Cap & 'Or & & & & Cal & 'Or \\
\hline Major & (wt \%) & & & & & & & & & & & & & \\
\hline $\mathrm{SiO}_{2}$ & 61.86 & 60.03 & 58.53 & 59.64 & 49.15 & 49.82 & 49.97 & 49.59 & 48.75 & 49.41 & 48.60 & 48.39 & 48.83 & 48.72 \\
\hline $\mathrm{Al}_{2} \mathrm{O}_{3}$ & 16.57 & 16.55 & 14.04 & 14.07 & 26.57 & 26.93 & 26.52 & 26.59 & 26.26 & 26.40 & 26.09 & 26.18 & 26.02 & 26.35 \\
\hline $\mathrm{CaO}$ & 5.72 & 5.16 & 4.22 & 3.19 & 0.29 & b.d. & 0.92 & 1.56 & 1.82 & b.d. & 0.21 & 0.29 & 3.28 & 1.94 \\
\hline $\mathrm{Na}_{2} \mathrm{O}$ & 1.17 & 2.26 & 4.33 & 4.39 & 15.56 & 16.19 & 15.06 & 14.92 & 14.18 & 16.00 & 15.41 & 15.16 & 12.41 & 13.98 \\
\hline $\mathrm{K}_{2} \mathrm{O}$ & 1.25 & 1.06 & 1.70 & 1.76 & b.d. & b.d. & b.d. & b.d. & b.d. & b.d. & b.d. & b.d. & b.d. & b.d. \\
\hline Total & 86.57 & 85.06 & 82.82 & 83.05 & 91.57 & 92.94 & 92.47 & 92.76 & 91.01 & 91.81 & 90.31 & 90.02 & 90.58 & 90.99 \\
\hline Molecular for & & & & & & & & & & & & & & \\
\hline Oxygen No. & 48 & 48 & 72 & 72 & 80 & 80 & 80 & 80 & 80 & 80 & 80 & 80 & 80 & 80 \\
\hline $\mathrm{Si}$ & 18.43 & 18.27 & 27.78 & 28.05 & 24.47 & 24.46 & 24.61 & 24.41 & 24.43 & 24.55 & 24.53 & 24.49 & 24.52 & 24.41 \\
\hline $\mathrm{Al}$ & 5.82 & 5.94 & 7.86 & 7.80 & 15.60 & 15.59 & 15.40 & 15.49 & 15.52 & 15.46 & 15.52 & 15.62 & 15.43 & 15.57 \\
\hline $\mathrm{Ca}$ & 1.83 & 1.68 & 2.15 & 1.61 & 0.16 & b.d. & 0.49 & 0.82 & 0.98 & b.d. & 0.11 & 0.16 & 1.77 & 1.04 \\
\hline $\mathrm{Na}$ & 0.68 & 1.33 & 3.99 & 4.00 & 15.02 & 15.41 & 14.38 & 14.24 & 13.78 & 15.41 & 15.08 & 14.88 & 12.09 & 13.58 \\
\hline K & 0.48 & 0.41 & 1.03 & 1.18 & b.d. & b.d. & b.d. & b.d. & b.d. & b.d. & b.d. & b.d. & b.d. & b.d. \\
\hline $\mathrm{Si} / \mathrm{Al}$ & 3.17 & 3.08 & 3.54 & 3.60 & 1.57 & 1.57 & 1.60 & 1.58 & 1.58 & 1.59 & 1.58 & 1.57 & 1.59 & 1.57 \\
\hline $\mathrm{E} \%$ & 21.2 & 16.2 & -15.6 & -7.1 & 1.7 & 1.1 & 0.3 & -2.5 & -1.4 & 0.3 & 1.4 & 2.8 & -1.2 & -0.6 \\
\hline
\end{tabular}


Table 2. Electron microprobe analyses of representative zeolite minerals from Kings County

\begin{tabular}{|c|c|c|c|c|c|c|c|c|c|c|c|c|}
\hline \multirow{4}{*}{$\begin{array}{l}\text { Mineral } \\
\text { Sample } \\
\text { Analysis No. } \\
\text { Locality }\end{array}$} & \multirow{2}{*}{\multicolumn{2}{|c|}{$\frac{\text { Mesolite }}{\text { Z33 }}$}} & \multirow{2}{*}{\multicolumn{4}{|c|}{$\frac{\text { Scolecite }}{\mathrm{Z} 23}$}} & \multirow{2}{*}{\multicolumn{2}{|c|}{$\frac{\text { Thomsonite }}{\text { Z33 }}$}} & \multicolumn{2}{|c|}{ Natrolite } & \multirow{2}{*}{\multicolumn{2}{|c|}{$\begin{array}{c}\text { Tetranatrolite } \\
\text { Z44 }\end{array}$}} \\
\hline & & & & & & & & & Z19 & $\mathrm{Z} 44$ & & \\
\hline & 771 & 772 & 859 & 860 & 862 & 863 & 773 & 774 & 877 & 710 & 714 & 715 \\
\hline & \multicolumn{8}{|c|}{ Arlington Quarry } & WC & $\mathrm{AC}$ & \multicolumn{2}{|c|}{ Amethyst Cove } \\
\hline \multicolumn{13}{|c|}{ Major elements (wt $\%)$} \\
\hline $\mathrm{SiO}_{2}$ & 45.53 & 45.09 & 46.17 & 45.55 & 45.76 & 46.07 & 38.58 & 38.42 & 47.06 & 47.22 & 47.20 & 47.08 \\
\hline $\mathrm{Al}_{2} \mathrm{O}_{3}$ & 25.40 & 25.12 & 24.38 & 24.78 & 25.19 & 24.66 & 30.17 & 29.15 & 26.25 & 26.55 & 26.41 & 26.40 \\
\hline $\mathrm{FeO}^{\mathrm{t}}$ & b.d. & b.d. & b.d. & b.d. & b.d. & b.d. & 0.50 & 1.80 & b.d. & b.d. & b.d. & b.d. \\
\hline $\mathrm{MgO}$ & b.d. & b.d. & b.d. & b.d. & b.d. & b.d. & 0.55 & 1.09 & b.d. & b.d. & b.d. & b.d. \\
\hline $\mathrm{CaO}$ & 9.15 & 9.04 & 14.34 & 14.55 & 14.71 & 14.55 & 13.50 & 12.75 & 1.43 & b.d. & 3.08 & 2.59 \\
\hline $\mathrm{Na}_{2} \mathrm{O}$ & 4.34 & 4.30 & b.d. & b.d. & b.d. & b.d. & 3.68 & 3.66 & 14.49 & 15.35 & 11.76 & 12.40 \\
\hline $\mathrm{K}_{2} \mathrm{O}$ & b.d. & b.d. & b.d. & b.d. & b.d. & b.d. & b.d. & b.d. & b.d. & b.d. & b.d. & b.d. \\
\hline Total & 84.42 & 83.55 & 84.89 & $\overline{84.88}$ & 85.66 & 85.28 & 87.25 & 86.78 & 89.23 & 89.12 & 88.45 & 88.47 \\
\hline \multicolumn{13}{|c|}{ Molecular Formula } \\
\hline Oxygen No. & 80 & 80 & 80 & 80 & 80 & 80 & 80 & 80 & 80 & 80 & 80 & 80 \\
\hline $\mathrm{Si}$ & 24.28 & 24.3 & 24.49 & 24.21 & 24.11 & 24.35 & 20.68 & 20.67 & 24.12 & 24.17 & 24.24 & 24.2 \\
\hline $\mathrm{Al}$ & 15.97 & 15.96 & 15.25 & 15.53 & 15.65 & 15.37 & 18.93 & 18.49 & 15.86 & 16.02 & 15.99 & 16 \\
\hline $\mathrm{Fe}$ & b.d. & b.d. & b.d. & b.d. & b.d. & b.d. & 0.22 & 0.81 & b.d. & b.d. & b.d. & b.d. \\
\hline $\mathrm{Mg}$ & b.d. & b.d. & b.d. & b.d. & b.d. & b.d. & 0.44 & 0.87 & b.d. & b.d. & b.d. & b.d. \\
\hline $\mathrm{Ca}$ & 5.23 & 5.22 & 8.15 & 8.29 & 8.31 & 8.24 & 7.7 & 7.35 & 0.79 & b.d. & 1.7 & 1.43 \\
\hline $\mathrm{Na}$ & 4.49 & 4.49 & b.d. & b.d. & b.d. & b.d. & 3.8 & 3.82 & 14.4 & 15.24 & 11.71 & 12.36 \\
\hline $\mathrm{K}$ & b.d. & b.d. & b.d. & b.d. & b.d. & b.d. & b.d. & b.d. & b.d. & b.d. & b.d. & b.d. \\
\hline $\mathrm{Si} / \mathrm{Al}$ & 1.52 & 1.52 & 1.55 & 1.56 & 1.54 & 1.59 & 1.09 & 1.12 & 1.52 & 1.51 & 1.52 & 1.51 \\
\hline $\mathrm{E} \%$ & 6.9 & 6.9 & -6.5 & -6.3 & -5.8 & -6.8 & -4.6 & -4.8 & -0.7 & 5.2 & 5.9 & 5.2 \\
\hline Mineral & \multicolumn{12}{|c|}{ "Heulandite" } \\
\hline Sample & \multicolumn{6}{|c|}{$\mathrm{Z30}$} & \multicolumn{2}{|c|}{ Z31 } & \multicolumn{2}{|c|}{$\mathrm{Z33}$} & \multicolumn{2}{|c|}{ Z36 } \\
\hline Analysis No. & 721 & 722 & 723 & 731 & 732 & 735 & 756 & 799 & 781 & 783 & 812 & 814 \\
\hline Locality & \multicolumn{12}{|c|}{ Arlington Quarry } \\
\hline \multicolumn{13}{|c|}{ Major elements (wt $\%)$} \\
\hline $\mathrm{SiO}_{2}$ & 66.38 & 65.26 & 63.85 & 57.82 & 59.38 & 61.86 & 61.47 & 57.9 & 56.73 & 57.3 & 59.71 & 59.68 \\
\hline $\mathrm{Al}_{2} \mathrm{O}_{3}$ & 12.37 & 12.73 & 12.77 & 15.94 & 16.57 & 17.8 & 17.05 & 16.41 & 18.2 & 17.69 & 16.29 & 16.43 \\
\hline $\mathrm{CaO}$ & 6.35 & 6.62 & 6.57 & 8.11 & 8.14 & 9.04 & 8.83 & 7.85 & 9.4 & 8.97 & 6.01 & 8.35 \\
\hline $\mathrm{Na}_{2} \mathrm{O}$ & 0.19 & 0.22 & 0.19 & 0.67 & 0.19 & 0.79 & 0.51 & 0.49 & 0.7 & 0.63 & 0.48 & 1.01 \\
\hline $\mathrm{K}_{2} \mathrm{O}$ & 0.21 & 0.22 & 0.28 & b.d. & 0.87 & b.d. & 0.2 & 1.37 & b.d. & b.d. & 3.14 & 0.54 \\
\hline Total & 85.5 & 85.05 & 83.66 & 82.54 & 85.15 & 89.49 & 88.06 & 84.02 & 85.03 & 84.59 & 85.63 & 86.01 \\
\hline \multicolumn{13}{|c|}{ Molecular Formula } \\
\hline Oxygen No. & 72 & 72 & 72 & 72 & 72 & 72 & 72 & 72 & 72 & 72 & 72 & 72 \\
\hline $\mathrm{Si}$ & 29.55 & 29.28 & 29.15 & 27.18 & 27.14 & 26.89 & 27.12 & 26.97 & 26.12 & 26.43 & 27.36 & 27.69 \\
\hline $\mathrm{Al}$ & 6.49 & 6.73 & 6.87 & 8.83 & 8.93 & 9.12 & 8.87 & 9.01 & 9.88 & 9.69 & 8.8 & 8.79 \\
\hline $\mathrm{Ca}$ & 3.03 & 3.18 & 3.21 & 4.09 & 3.99 & 4.21 & 4.18 & 3.92 & 9.4 & 8.97 & 2.95 & 4.06 \\
\hline $\mathrm{Na}$ & 0.16 & 0.19 & 0.17 & 0.61 & 0.17 & 0.67 & 0.44 & 0.44 & 0.7 & 0.63 & 0.43 & 0.89 \\
\hline $\mathrm{K}$ & 0.12 & 0.13 & 0.16 & b.d. & 0.51 & b.d. & 0.11 & 0.81 & b.d. & b.d. & 1.84 & 0.31 \\
\hline $\mathrm{Si} / \mathrm{Al}$ & 4.55 & 4.35 & 4.25 & 3.08 & 3.04 & 2.95 & 3.09 & 2.99 & 2.64 & 2.73 & 3.09 & 3.08 \\
\hline $\mathrm{E} \%$ & 2.4 & 0.8 & 1.7 & 0.6 & 3.2 & 0.4 & -0.3 & -0.9 & -0.2 & 2 & 7.8 & -5.7 \\
\hline
\end{tabular}

Notes: $\mathrm{WC}=$ Woodworth Cove, $\mathrm{AC}=$ Amethyst Cove 
Table 2. (contd.)

\begin{tabular}{|c|c|c|c|c|c|c|c|c|c|c|c|c|}
\hline \multirow{4}{*}{$\begin{array}{l}\text { Mineral } \\
\text { Sample } \\
\text { Analysis No. } \\
\text { Locality }\end{array}$} & \multicolumn{6}{|c|}{ Epistilbite } & \multicolumn{6}{|c|}{ Stilbite } \\
\hline & \multicolumn{4}{|c|}{$\mathrm{Z} 21$} & \multicolumn{2}{|c|}{ Z33 } & \multicolumn{2}{|c|}{$\mathrm{Z} 25$} & \multicolumn{2}{|c|}{ Z30 } & \multicolumn{2}{|c|}{ Z31 } \\
\hline & 761 & 764 & 766 & 767 & 777 & 778 & 843 & 844 & 724 & 726 & 754 & 785 \\
\hline & \multicolumn{12}{|c|}{ Arlington Quarry } \\
\hline \multicolumn{13}{|c|}{ Major elements (wt $\%)$} \\
\hline $\mathrm{SiO}_{2}$ & 58.31 & 60.39 & 59.7 & 61.9 & 56.85 & 58.88 & 57.23 & 57.28 & 57.34 & 56.94 & 57.31 & 56.92 \\
\hline $\mathrm{Al}_{2} \mathrm{O}_{3}$ & 17.12 & 16.36 & 16.38 & 16.41 & 18.45 & 17.52 & 15.57 & 15.79 & 15.89 & 15.41 & 15.79 & 15.32 \\
\hline $\mathrm{CaO}$ & 8.51 & 8.67 & 8.32 & 8.34 & 9.4 & 9.01 & 7.67 & 6.8 & 8.22 & 8.04 & 8.13 & 8.07 \\
\hline $\mathrm{Na}_{2} \mathrm{O}$ & 1.23 & 0.59 & 0.98 & 0.31 & 0.62 & 0.57 & 1.02 & 1.68 & 1.2 & 0.69 & 0.76 & 0.34 \\
\hline $\mathrm{K}_{2} \mathrm{O}$ & b.d. & b.d. & b.d. & 0.29 & b.d. & b.d. & 0.74 & 0.99 & b.d. & b.d. & b.d. & b.d. \\
\hline Total & 85.17 & 86.01 & 85.38 & 87.25 & 85.32 & 85.98 & 82.23 & 82.74 & 82.65 & 81.08 & 81.99 & 80.65 \\
\hline \multicolumn{13}{|c|}{ Molecular Formula } \\
\hline Oxygen No. & 48 & 48 & 48 & 48 & 48 & 48 & 72 & 72 & 72 & 72 & 72 & 72 \\
\hline $\mathrm{Si}$ & 17.8 & 18.17 & 18.11 & 18.31 & 17.38 & 17.78 & 27.17 & 27.15 & 27.03 & 27.26 & 27.15 & 27.34 \\
\hline $\mathrm{Al}$ & 6.16 & 5.8 & 5.86 & 5.72 & 6.65 & 6.24 & 8.71 & 8.79 & 8.83 & 8.7 & 8.82 & 8.68 \\
\hline $\mathrm{Ca}$ & 2.78 & 2.79 & 2.7 & 2.64 & 3.08 & 2.92 & 2.9 & 3.44 & 4.15 & 4.12 & 4.13 & 4.15 \\
\hline $\mathrm{Na}$ & 0.73 & 0.34 & 0.58 & 0.18 & 0.37 & 0.33 & 0.94 & 1.54 & 1.1 & 0.64 & 0.7 & 0.32 \\
\hline $\mathrm{K}$ & b.d. & b.d. & b.d. & 0.11 & b.d. & b.d. & 0.49 & 0.6 & b.d. & b.d. & b.d. & b.d. \\
\hline $\mathrm{Si} / \mathrm{Al}$ & 2.89 & 3.13 & 3.19 & 3.2 & 2.61 & 2.85 & 3.12 & 3.13 & 3.06 & 3.13 & 3.08 & 3.15 \\
\hline $\mathrm{E} \%$ & -2.1 & -2.2 & -2.1 & 2.7 & 1.9 & 1.2 & -5.2 & -2.5 & -6.1 & -2.2 & -1.5 & 0.6 \\
\hline Mineral & \multicolumn{9}{|c|}{ Stilbite } & \multicolumn{2}{|c|}{ Stellerite } & \\
\hline Sample & \multicolumn{6}{|c|}{$\mathrm{Z31}$} & \multicolumn{3}{|c|}{$\mathrm{Z} 33$} & \multicolumn{2}{|c|}{$\mathrm{Z} 40$} & \\
\hline Analysis No. & 786 & 789 & 792 & 794 & 798 & 802 & 947 & 948 & 949 & 852 & 174 & \\
\hline Locality & \multicolumn{11}{|c|}{ Arlington Quarry } & \\
\hline \multicolumn{13}{|c|}{ Major elements (wt\%) } \\
\hline $\mathrm{SiO}_{2}$ & 55.85 & 56.76 & 55.66 & 57.62 & 57.65 & 55.22 & 58.21 & 60.36 & 59.47 & 56.64 & 57.72 & \\
\hline $\mathrm{Al}_{2} \mathrm{O}_{3}$ & 15.61 & 15.82 & 15.39 & 16.21 & 16.2 & 15.42 & 16.76 & 15.78 & 15.63 & 16.49 & 16.51 & \\
\hline $\mathrm{CaO}$ & 8.18 & 8.35 & 8.32 & 7.64 & 7.29 & 7.03 & 7.97 & 7.96 & 7.71 & 8.67 & 8.37 & \\
\hline $\mathrm{Na}_{2} \mathrm{O}$ & 0.51 & 1.17 & 1.16 & b.d. & b.d. & 0.29 & 0.55 & 0.52 & 0.39 & 1.63 & 0.78 & \\
\hline $\mathrm{K}_{2} \mathrm{O}$ & 0.2 & b.d. & 0.2 & 1.41 & 1.72 & 1.33 & 0.31 & 0.33 & 0.3 & b.d. & b.d. & \\
\hline Total & 80.35 & 82.1 & 80.73 & 82.91 & 82.86 & 79.29 & 83.8 & 84.95 & 83.5 & 83.43 & 83.38 & \\
\hline \multicolumn{13}{|c|}{ Molecular Formula } \\
\hline Oxygen No. & 72 & 72 & 72 & 72 & 72 & 72 & 72 & 72 & 72 & 72 & 72 & \\
\hline $\mathrm{Si}$ & 27.04 & 26.96 & 26.95 & 27.12 & 27.16 & 27.16 & 26.98 & 27.53 & 27.55 & 26.60 & 26.92 & \\
\hline $\mathrm{Al}$ & 8.91 & 8.86 & 8.79 & 8.99 & 9.00 & 8.94 & 9.16 & 8.49 & 8.54 & 9.13 & 9.08 & \\
\hline $\mathrm{Ca}$ & 4.24 & 4.25 & 4.32 & 3.85 & 3.68 & 3.71 & 3.96 & 3.89 & 3.83 & 4.36 & 4.18 & \\
\hline $\mathrm{Na}$ & 0.48 & 1.08 & 1.09 & b.d. & b.d. & 0.28 & 0.49 & 0.46 & 0.35 & 1.48 & 0.71 & \\
\hline $\mathrm{K}$ & 0.12 & b.d. & 0.12 & 0.85 & 1.03 & 0.84 & 0.18 & 0.19 & 0.18 & b.d. & b.d. & \\
\hline $\mathrm{Si} / \mathrm{Al}$ & 3.04 & 3.04 & 3.29 & 3.02 & 3.02 & 3.04 & 2.95 & 3.24 & 3.23 & 2.91 & 2.97 & \\
\hline E\% & -2.0 & -7.5 & -10.8 & 5.2 & 7.2 & 4.9 & 6.6 & 0.6 & 4.3 & -10.6 & 0.1 & \\
\hline
\end{tabular}


also been identified. The associated minerals include quartz, other forms of silica, malachite and magnetite. Data are insufficient to determine an overall order of crystallization, but sequences of quartz to stilbite, quartz to "heulandite", stilbite to laumontite, and mesolite to quartz are seen.

\section{MINERAL CHEMISTRY}

Selected chemical analyses of zeolite minerals from the North Shore of Minas Basin are given in Table 1. Where possible, analyses with a chemical balance error (E) (Passaglia 1975) of $<10 \%$ are given in the table and illustrated in Figures 5 and 6, but in cases where no other analyses were available, some analyses with higher balance errors are included. The chemical compositions of individual zeolite minerals can be illustrated on a $\mathrm{Na}$ - K - (Ca+Mg) plot (Fig. 5a). Na-rich zeolites are represented by natrolite, tetranatrolite, and gmelinite. Chabazite shows a wide range of compositions from almost zero to $65 \% \mathrm{Ca}+\mathrm{Mg}$. Stilbite and epistilbite show a wider range in $K$ content than that reported by Pe-Piper (2000) from Morden. The chemical range of "heulandite" is similar to that at Morden (Pe-Piper 2000), except that no Na-clinoptilolite or K-heulandite has been found in the present study. Thomsonite, mesolite, and wairakite have narrow compositional ranges. However, many analysed zeolites from the North Shore have a higher sodium content compared with published values from elsewhere (Gottardi and Galli 1985).

On a Si/Al - $(\mathrm{Ca}+\mathrm{Mg}) /(\mathrm{Na}+\mathrm{K})$ plot (Fig. 6a), two types of "heulandite" can be distinguished. Clinoptilolite has $\mathrm{Si} / \mathrm{Al}>4$, whereas heulandite (sensu stricto) has values between 2.5 and 3. Stilbite generally has a Si/Al ratio between 2.8 and 3.1. Chabazite of the North Shore has a wide range of compositions, but within the range reported by Gottardi and Galli (1985). Most other minerals show a narrow range of compositions, particularly in Si/Al ratio.

\section{COMPARISON OF NORTH SHORE WITH KINGS COUNTY}

\section{Introduction}

Arlington Quarry (Fig. 1) was selected as a representative zeolite-bearing locality from the North Mountain Basalt of Kings County. Sixty-three zeolite samples from the quarry were studied in hand specimen (Fig. 7) and by XRD and electron microprobe. Nine types of zeolite were identified: epistilbite, scolecite, stilbite, stellerite, heulandite (sensu stricto), clinoptilolite, mesolite, thomsonite, and rare analcime (Table 2). Minerals associated with the zeolites include green celadonite, malachite, quartz and other forms of silica, barite, calcite, and fluoroapophyllite. The following sequences of crystallization are recognised, from early to late:

Heulandite (sensu stricto) to clinoptilolite to stilbite Heulandite (sensu stricto) to stilbite to clinoptilolite "Heulandite" to silica minerals to "heulandite" to stilbite
Thomsonite and/or epistilbite to mesolite

Stellerite to "heulandite"

Scolecite to stilbite

\section{Mineral chemistry: North Shore vs. Arlington Quarry}

Chemical analyses of zeolite minerals from Arlington Quarry are given in Table 2. "Heulandite", mesolite, stilbite, thomsonite, natrolite, tetranatrolite, and epistilbite have been analysed from both the North Shore and Arlington Quarry and can therefore be compared.

"Heulandite" from Arlington Quarry is generally pink, earthy, and massive, and shows three clusters in terms of $\mathrm{Si} / \mathrm{Al}$ ratio at $\sim 4.5, \sim 3.1$, and $\sim 2.8$ (Fig. 6b). In individual crystals, Si content decreases from core to rim, whereas $\mathrm{Al}$ and $\mathrm{K}$ increase, and $\mathrm{Ca}$ first increases and then decreases. The "heulandite" from the North Shore shows the same clusters of Si/Al ratio (Fig. 6a), less Ca, and more $\mathrm{K}$ and $\mathrm{Na}$; minor $\mathrm{Mg}$ was also detected. As a result, average $(\mathrm{Ca}+\mathrm{Mg}) /(\mathrm{Na}+\mathrm{K})$ is lower (Fig. 6a) than at Arlington Quarry. Within individual crystals, $\mathrm{Ca}$ and $\mathrm{K}$ generally decrease from core to rim, whereas $\mathrm{Na}$ and $\mathrm{Si}$ increase.

Mesolite of Arlington Quarry is white and dull, resembling that of the North Shore in hand specimen. Within individual crystals $\mathrm{Si}, \mathrm{Al}, \mathrm{Ca}, \mathrm{Na}$, and $\mathrm{H}_{2} \mathrm{O}$ decrease from core to rim. In contrast to Arlington Quarry, within individual crystals of mesolite from the North Shore, $\mathrm{Si}, \mathrm{Al}$, and $\mathrm{Ca}$ increase from core to rim and $\mathrm{K}$ was detected, but $(\mathrm{Ca}+\mathrm{Mg}) /(\mathrm{Na}+\mathrm{K})$ from the two areas is similar.

Stilbite from Arlington Quarry is generally sheaf-like, vitreous, and colourless, resembling that of the North Shore. Analyses of stilbite from the two areas shows similar Si/Al and $(\mathrm{Ca}+\mathrm{Mg}) /(\mathrm{Na}+\mathrm{K})$ ratios (Fig. 6). Within individual crystals at Arlington Quarry, Si, $\mathrm{Na}$, and $\mathrm{K}$ decrease from core to rim, whereas $\mathrm{Al}$ and $\mathrm{Ca}$ increase. In contrast, individual crystals from the North Shore show Si and $\mathrm{Ca}$ increasing from core to rim, and $\mathrm{Al}$ and $\mathrm{Na}$ decreasing.

Epistilbite is not easy to identify in hand specimen and most of the epistilbite identifications are from XRD and electron microprobe chemical analyses. The Si/Al ratios of epistilbite from both areas are similar, but epistilbite from the North Shore has lower $\mathrm{Al}$ and $\mathrm{Ca}$ and higher $\mathrm{Na}$. The natrolite and tetranatrolite from Arlington Quarry in hand specimen do not differ from those from North Shore and their chemical characteristics are also similar (Fig. 6).

Thomsonite from Arlington Quarry is generally white, dull, and massive with Si/Al average of 1.10 (Fig. 6a). Within individual crystals, $\mathrm{Si}, \mathrm{Al}, \mathrm{Ca}$, and $\mathrm{Na}$ generally decrease from core to rim, whereas Fe and Mg decrease. Thomsonite from the North Shore has a higher Si/Al ratio average of 1.25 (Fig. 6a), lower Fe, Mg, and $\mathrm{Ca}$, and $\mathrm{Na}$ increases from core to rim of individual crystals. $\mathrm{Fe}$, $\mathrm{Mg}$, and $\mathrm{K}$ were not detected.

In both Figs. 5 and 6, zeolites from Arlington Quarry cluster much more tightly than those from the North Shore. This effect is not simply the result of a greater geographic range on the North Shore, as analyses from the Morden area reported by Pe-Piper (2000), from localities up to $30 \mathrm{~km}$ apart, show tight clusters simi- 

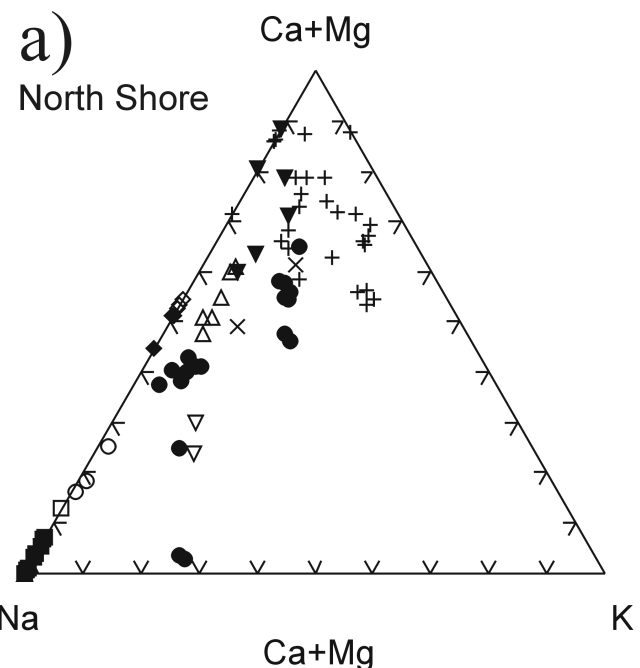

b)
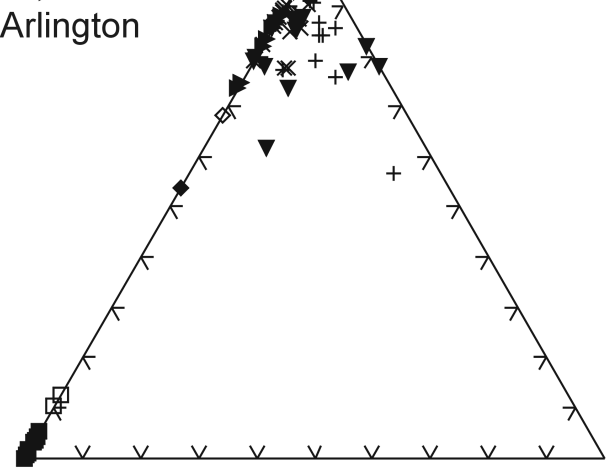

$\mathrm{Na}$

$\mathrm{K}$

\begin{tabular}{|lll|}
\hline Mesolite & $\times$ Epistilbite & $\circ$ Gmelinite \\
$\diamond$ Thomsonite & $\nabla$ Stilbite & $\Delta$ Analcime \\
- Natrolite & $\nabla$ Barrerite & $\Delta$ Wairakite \\
$\square$ Tetranatrolite & $\nabla$ Stellerite & $\Delta$ Scolecite \\
+ "Heulandite" & $\bullet$ Chabazite &
\end{tabular}

FIG. 5 Plot of zeolite compositions in terms of $(\mathrm{C} a+\mathrm{Mg})-\mathrm{Na}-\mathrm{K}$ (electron-microprobe data for which $E$ is less than 10\%).

lar to those from Arlington Quarry. At both Arlington Quarry and the Morden area (Pe-Piper 2000), few zeolites fall in the field in Figure 5 with either $\mathrm{Ca}+\mathrm{Mg}<70 \%$ or $\mathrm{Na}<70 \%$. In contrast, on the North Shore, all epistilbite, thomsonite, and mesolite analyses lie in this field, together with wairakite and many chabazite analyses, two minerals not analyzed from Kings County.

\section{DISCUSSION}

\section{Minerals present}

All zeolite minerals previously reported from the North Mountain Basalt, except gyrolite, levyne, and mordenite, have also been identified along the North Shore of the Minas Basin. In addition, wairakite, barrerite, and tetranatrolite, not previously reported, have been identified. Scolecite has been identified only a)

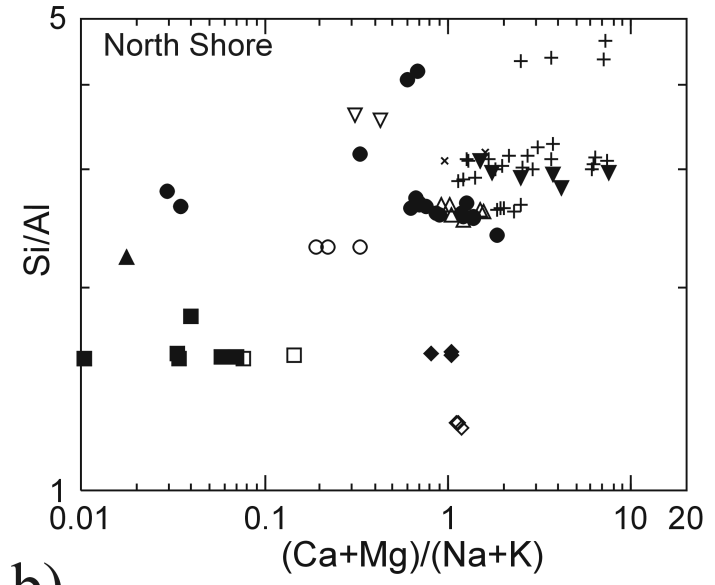

b)

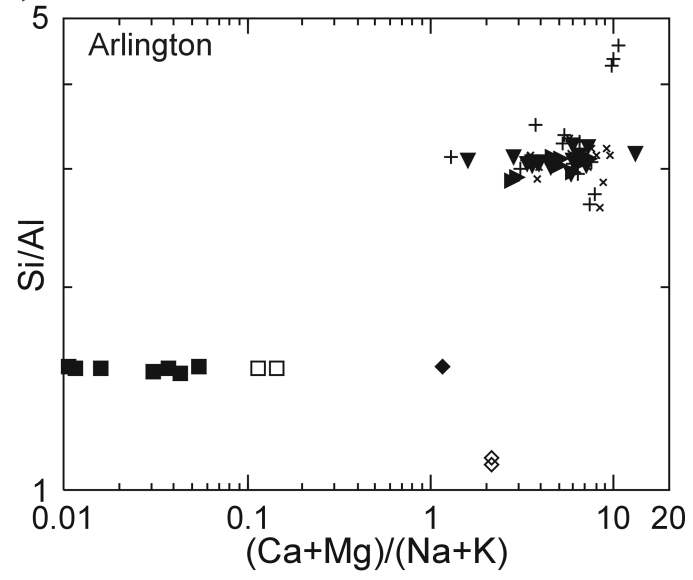

\begin{tabular}{|lll|}
\hline Mesolite & $\times$ Epistilbite & $\circ$ Gmelinite \\
$\diamond$ Thomsonite & $\nabla$ Stilbite & $\Delta$ Analcime \\
- Natrolite & $\nabla$ Barrerite & $\Delta$ Wairakite \\
$\square$ Tetranatrolite & $\nabla$ Stellerite & $\Delta$ Scolecite \\
+ "Heulandite" & $\bullet$ Chabazite &
\end{tabular}

FIG. 6 Plot of Si/Al against $(\mathrm{C} a+\mathrm{Mg}) /(\mathrm{Na}+\mathrm{K})$ for zeolite-group minerals (electron-microprobe data for which $\mathrm{E}$ is less than 10\%).

by $\mathrm{XRD}$ and some massive samples described as scolecite on the basis of hand specimen character were identified as mesolite by $\mathrm{XRD}$ and electron microprobe.

The zeolite minerals found on the North Shore of the Minas Basin differ from those in Kings County and elsewhere on the south coast of the Bay of Fundy in the presence of wairakite and barrerite, and in the abundance of chabazite, which is rare on the south coast. Chabazite was reported by Sabina (1965) from Mink Cove and Cape Split, but we have found no samples at Arlington Quarry and Morden (Pe-Piper 2000). Mordenite, which is common in Kings County, has not been found on the North Shore of the Minas Basin.

\section{Hydrothermal origin of zeolites}

Previous studies suggested that the zeolite formation in the North Mountain Basalt was the result of burial metamorphism 

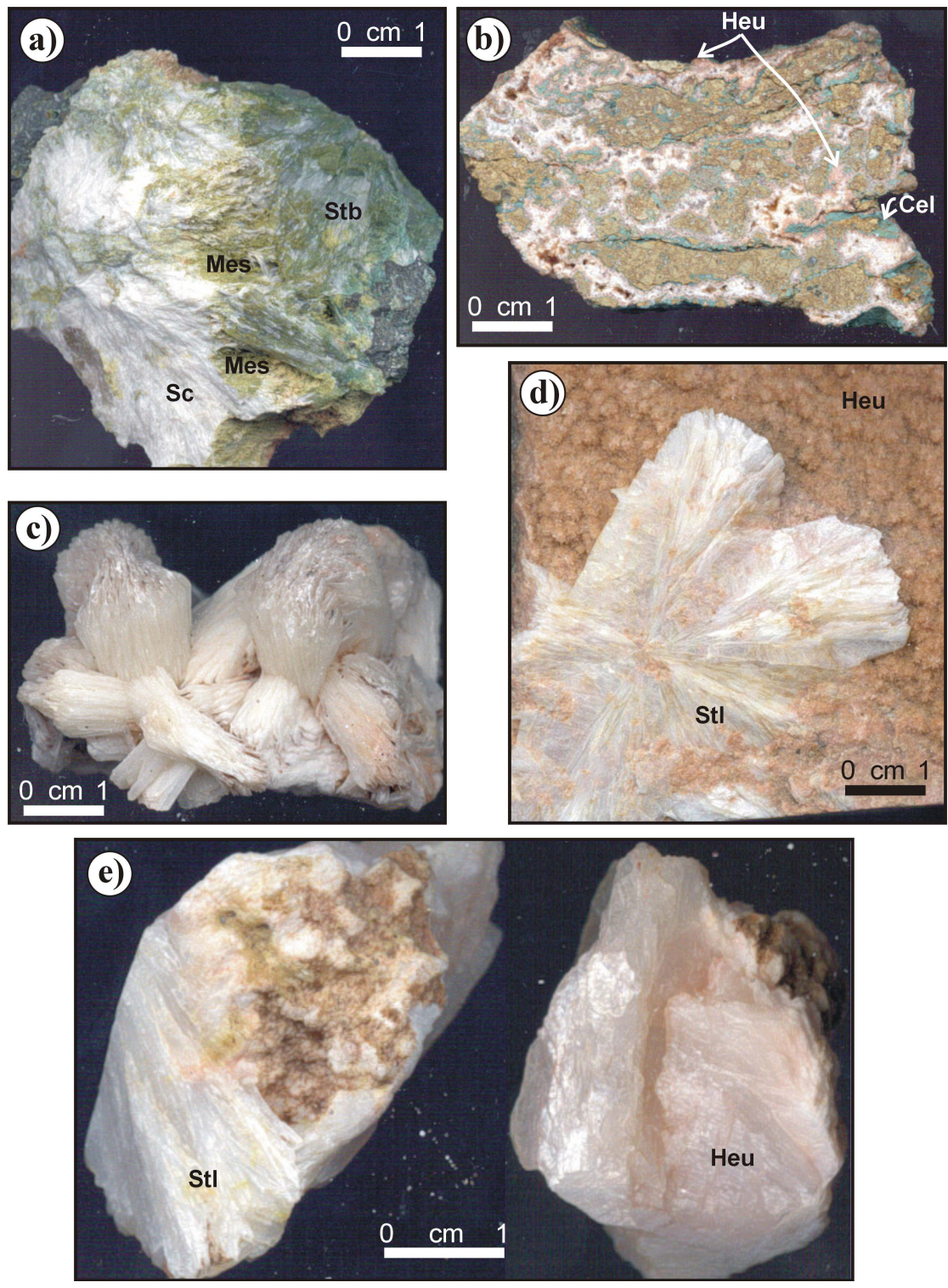

FIG. 7 Photos of representative hand specimens from Arlington Quarry. a) Green-colourless platy crystals of epistilbite (Esb) associated with white to brownish fibrous crystals of mesolite (Mes) and white, acicular to fibrous crystals of scolecite (Sc), sample Z21B. b) Vesicular basalt with vesicles filled with "heulandite" (Heu) and stilbite (Stb) and rimmed with celadonite (Cel).c) Transparent colourless blades of epistilbite, sample Z28. d) Blades of stellerite ((Stl) in star-type arrangement on a mixture of fibres and grains of pinkish "heulandite," sample Z36. e) Fibrous stellerite (Stl) associated with blades of "heulandite"(Heu), sample Z40.

(e.g. Aumento 1966; Adams 1980). New petrographic evidence in Pe-Piper (2000), such as the repetitive zonation in some amygdales and the amount of metal precipitates, suggest a hydrothermal origin. The difference in chemical composition of zeolite minerals from the North Shore of the Minas Basin and from Kings County may be the result of a difference in temperature of formation and/or different fluid composition.

\section{Temperatures of zeolite formation}

Recent experimental data on the formation temperatures of natural zeolites are limited. Barth-Wirshing and Holler (1989) suggested that chabazite forms from basaltic glass at temperatures of $50-150^{\circ} \mathrm{C}$, whereas heulandite forms from rhyolitic glass at temperatures of $150-225^{\circ} \mathrm{C}$. The dominance of "heulandite" in Kings County and of chabazite on the North Shore suggests that formation temperatures were higher in Kings County. This differentce is also supported by the presence of mordenite in some areas of Kings County (Pe-Piper 2000; Kontak 2000). 
In general, Ca ions can crystallize out of aqueous solution at much higher temperatures than Na and K (Kotz and Purcell 1987, p. 756-765). High-temperature solutions are thus more likely to precipitate Ca-rich zeolites than Na-rich zeolites. The first zeolite minerals to crystallize in Kings County samples are rich in $\mathrm{Ca}$ (i.e. "heulandite") and we infer that $\mathrm{Na}$ was not accommodated in the crystal structure of the crystallizing zeolites because fluid temperature was too high. As the temperatures decreased and the circulating fluids became depleted in $\mathrm{Ca}$, lower temperature, $\mathrm{Na}$ rich zeolites (natrolite group) began to crystallize. In contrast, on the North Shore the chemical data presented in this paper indicate that Na was readily accommodated in the crystal structure of crystallizing zeolites, which we interpret as a result of crystallization at lower temperatures. As a result, only limited crystallization of Na-rich zeolites (natrolite group) took place in the North Shore occurrences, and the observed zeolites show a broad scatter in $\mathrm{Na}$, $\mathrm{Ca}, \mathrm{Mg}$, and $\mathrm{K}$ (Fig. 5).

Chemical differences between zeolites of the North Shore and Kings County may also result from different chemistry of crystallizing solutions. Pe-Piper (2000) proposed that the abundance of mordenite in Kings County was in part related to extraction of $\mathrm{Na}$ from evaporites of the Blomidon Formation. According to Ackermann et al. (1995), the Blomidon Formation contains a chaotic mudstone which can be traced for $35 \mathrm{~km}$ in the Fundy Rift Basin. Ackermann et al. (1995) inferred the unit was formed by subsidence and collapse of a metre thick evaporite-rich bed by groundwater. On the North Shore of the Minas Basin, Mertz and Hubert (1990) described only gypsum precipitation. The variation in evaporite distribution in the Blomidon Formation, from gypsum at the basin margin to halite in the basin centre, may have influenced the chemistry of later hydrothermal zeolites.

\section{CONCLUSIONS}

The zeolite minerals identified on the North Shore of the Minas Basin include "heulandite", chabazite, gmelinite, analcime, wairakite, stilbite, barrerite, natrolite, scolecite, mesolite, thomsonite, laumontite, stellerite, tetranatrolite, and epistilbite. The most common zeolite minerals in this area are chabazite, "heulandite", stilbite, and analcime. Zeolite minerals identified in this study at Arlington Quarry (representative locality from Kings County) include heulandite (sensu stricto), clinoptilolite, stilbite, stellerite, scolecite, analcime, epistilbite, thomsonite, and mesolite. Other identified zeolites from elsewhere in Kings County include mordenite, natrolite, tetranatrolite, rare chabazite, analcime, laumontite, gmelinite, and gyrolite (Pe-Piper and Horton 1996; Pe-Piper 2000; and unpublished data). The dominant zeolite minerals in Kings County are "heulandite" and stilbite.

At Wasson Bluff, celadonite, silica minerals, "heulandite", analcime, and chabazite in amygdales in the basalt flows and in basalt clasts in the McCoy Brook Formation formed before deposition of the McCoy Brook Formation sedimentary rocks began. Veins and concretions of "heulandite", chabazite, stellerite, and silica minerals in these sedimentary rocks are later.

Overall evidence presented in this study suggests that the tem- perature of zeolite crystallization was higher in Arlington Quarry compared to the North Shore. Heulandite (sensu stricto) and stilbite are abundant in Arlington Quarry and very little Na was accommodated in their crystal structures. As temperatures fell, $\mathrm{Na}$ enrichment of the circulating fluids resulted in crystallization of Na-rich zeolite minerals, such as natrolite. In comparison, on the North Shore the temperature of zeolite formation was probably lower, so that Na was accommodated in the structure of chabazite and other zeolites (e.g., analcime) and finally only small amounts of Na-rich zeolites (natrolite group) crystallized at the lowermost temperatures. Chemical variation between individual zeolite minerals is likely also be a result of different fluid composition of the hydrothermal waters responsible for zeolite formation.

\section{ACKNOWLEDGEMENTS}

This work was supported partly by the Natural Sciences and Engineering Council of Canada Research Grant. Electron-microprobe analyses were conducted at the Regional Microprobe Centre at Dalhousie University and the XRD analyses at the Geological Survey of Canada (Atlantic). We thank D.J.W Piper for help in the field and for reviewing the paper. Journal reviews by John Greenough, Greg McHone and David McMullin substantially improved this paper.

\section{REFERENCES}

Ackermann, R.V., Schlische, R.W., \& Olsen, P.E. 1995. Syn-sedimentary collapse of portions of the lower Blomidon Formation, Fundy rift basin, Nova Scotia. Canadian Journal of Earth Sciences, v. 32, pp. 1965-1976.

Adams, G.C. 1980. A study of the zeolites of the North Mountain Basalt in the core GAV-77-3. B.Sc. (hons) thesis, Acadia University, Wolfville, N.S., 48 p.

Appleman, D.E., \& Evans, H,T., JR 1973. Job 9214: indexing and least squares refinement of powder diffraction data. U.S. Dept. of Commerce, NTIS Document, PB-21188.

Aumento, F. 1966. Zeolite minerals, Nova Scotia. In: Poole, W.J. (ed), Geology of parts of the Atlantic Provinces. Geological Association of Canada and Mineralogical Association of Canada, Field Trip 3, pp. 71-94.

Barth-Wirsching, U., \& Holler, H. 1989. Experimental studies on zeolite formation conditions. European Journal of Mineralogy, v. 1, pp. 489-506.

Воотн, I. 1994. Zeolites of the Bay of Fundy. Book privately published, $37 \mathrm{p}$.

DeWet, C.C.B., \& Hubert, J.F. 1989. The Scots Bay Formation, Nova Scotia, Canada, a Jurassic carbonate lake with silica-rich hydrothermal springs. Sedimentology, v. 36, pp. 857-873.

Donohoe, H.V. Jr., Colwell, J.A., \& George, E. 1992. Zeolites of the North Mountain Basalt, Bay of Fundy - Minas Basin region, Nova Scotia. Fieldtrip guide for the International Zeolite Association, 9th International Zeolite Conference, Montreal, Quebec, Canada, pp. 5-26 
Gesner, A. 1836. Remarks on the Geology and Mineralogy of Nova Scotia. Gossip and Coade, Times Office, Halifax, N.S.

Gilpin, E. 1881. The trap minerals of Nova Scotia. Nova Scotian Institute of Science, Transactions and Proceedings, v. 5, p. 283-296.

GotTARdi, G., \& Galli, E. 1985. Natural zeolites. Springer-Verlag, Berlin, $409 \mathrm{p}$.

Greenough, J.D., Jones, L.M., \& Mossman, D.J. 1989. Petrochemical and stratigraphic aspects of the North Mountain basalt from the north shore of the Bay of Fundy, Nova Scotia, Canada. Canadian Journal of Earth Sciences, v. 26, pp. 2710-2717.

How, H. 1868. The mineralogy of Nova Scotia: a report to the provincial government. Halifax, N.S., 217 p.

Jackson, C.T., \& Alger, F. 1828. A description of the mineralogy and geology of a part of Nova Scotia. American Journal of Science, v. 14, pp. 305-330.

KontaK, D.J. 2000. New insights into the classification and formation of zeolites hosted by the North Mountain Basalt, Annapolis Valley, southern Nova Scotia. Atlantic Geoscience Society, Annual Colloquium, Program with Abstracts, p. 31.

Kotz, J.C., \& Purcell, K.F. 1987. Chemistry and Chemical Reactivity. Saunders College Publishing, Montreal, 1020 p.

Mertz, K.A., JR., \& Hubert, J.F. 1990. Cycles of sand-flat sandstone and playa-lacustrine mudstone in the Triassic-Jurassic Blomidon redbeds, Fundy rift basin, Nova Scotia: implications for tectonic and climatic controls. Canadian Journal of Earth Sciences, v. 27, pp. 442-451.

Miller, L.J. 1997. Mode of occurrence, chemical variations and genesis of the zeolite minerals from the North Shore of the Minas Basin, Nova Scotia. B.Sc. (hons) thesis, Saint Mary's University, Halifax, N.S., 129 p.

Olsen, P.E. 1989. Stop 11.2, Five Islands Provincial Park. In: Tectonic, depositional, and paleoecological history of Early Mesozoic rift basins, eastern North America. Edited by P.E. Olsen and P.J.W. Gore, Field trip guidebook T351, 28th Geological Congress, pp. 150-151.
Passaglia, E. 1975. The crystal chemistry of mordenites. Contributions to Mineralogy and Petrology, v. 50, pp. 65-77.

Pe-Piper, G. 2000. Mode of occurrence, chemical variation and genesis of mordenite and other associated zeolites from Morden, Nova Scotia, Canadian Mineralogist, v.38, pp. 1215-1232.

Pe-Piper, G. and Horton, D. 1996. Zeolite mineral assemblages in the North Mountain Basalt, Nova Scotia. Nova Scotia Department of Natural Resources, Mines and Energy Branch, Open File Report 96-001, 30 p.

Sabina, A.P. 1965. Rock and mineral collecting in Canada. Vol. III, New Brunswick, Nova Scotia, Prince Edward Island, Newfoundland. Geological Survey of Canada Miscellaneous Report $8,106 \mathrm{p}$.

Schlische, R.W. and Olsen, P.E. 1989. Stop 11.3, Wasson Bluff. Structural Geology and Stratigraphy. In: Tectonic, depositional, and paleoecological history of Early Mesozoic rift basins, eastern North America. Edited by P.E. Olsen and P.J.W. Gore, Field trip guidebook T351, 28th Geological Congress, pp. 152-159.

SteVens, G.R. 1987. Jurassic basalts of the northern Bay of Fundy region, Nova Scotia. Geological Society of America Centennial Field Guide, Northeastern Section, v. 5, pp. 415-420.

TANNER, L.H., \& Hubert, J.F. 1991. Basalt breccias and conglomerates in the Lower Jurassic McCoy Brook Formation, Fundy Basin, Nova Scotia: differentiation of talus and debris-flow deposits. Journal of Sedimentary Petrology, v. 61, pp. 15-27.

Walker, T.L., \& Parsons, A.L. 1922. The zeolites of Nova Scotia. University of Toronto Studies, Series 14, Contributions to Canadian Mineralogy, pp. 13-73.

Withjack, M.O., Olsen, P.E., \& Schlische, R.W. 1995. Tectonic evolution of Fundy basin, Canada: Evidence for extension and shortening during passive margin formation. Tectonics, v. 40, pp. 390-405.

Editorial responsibility: Sandra M. Barr 